University of Nebraska - Lincoln

DigitalCommons@University of Nebraska - Lincoln

Papers in the Earth and Atmospheric Sciences Earth and Atmospheric Sciences, Department

$5-15-2003$

\title{
A Late Quaternary diatom record of tropical climatic history from Lake Titicaca (Peru and Bolivia)
}

\author{
Pedro M. Tapia \\ University of Nebraska-Lincoln \\ Sherilyn C. Fritz \\ University of Nebraska-Lincoln, sfritz2@unl.edu \\ Paul A. Baker \\ Duke University, pbaker@duke.edu \\ Geoffrey A. Seltzer \\ Syracuse University \\ Robert B. Dunbar \\ Stanford University
}

Follow this and additional works at: https://digitalcommons.unl.edu/geosciencefacpub

Part of the Earth Sciences Commons

Tapia, Pedro M.; Fritz, Sherilyn C.; Baker, Paul A.; Seltzer, Geoffrey A.; and Dunbar, Robert B., "A Late Quaternary diatom record of tropical climatic history from Lake Titicaca (Peru and Bolivia)" (2003). Papers in the Earth and Atmospheric Sciences. 34.

https://digitalcommons.unl.edu/geosciencefacpub/34

This Article is brought to you for free and open access by the Earth and Atmospheric Sciences, Department of at DigitalCommons@University of Nebraska - Lincoln. It has been accepted for inclusion in Papers in the Earth and Atmospheric Sciences by an authorized administrator of DigitalCommons@University of Nebraska - Lincoln. 
Published in Palaeogeography, Palaeoclimatology, Palaeoecology 194:1-3 (May 15, 2003), pp. 139-164; doi:10.1016/S0031-0182(03)00275-X Special issue on "Late-quaternary palaeoclimates of the southern tropical Andes and adjacent regions” Copyright (C) 2003 Elsevier Science B.V. Used by permission.

http://www.sciencedirect.com/science/journal/00310182

Accepted January 17, 2003; published online March 26, 2003.

\title{
A Late Quaternary diatom record of tropical climatic history from Lake Titicaca (Peru and Bolivia)
}

\author{
Pedro M. Tapia ${ }^{\mathrm{a}, *}$, Sherilyn C. Fritz ${ }^{\mathrm{a}}$, Paul A. Baker ${ }^{\mathrm{b}}$, \\ Geoffrey O. Seltzer ${ }^{c}$, and Robert B. Dunbar ${ }^{d}$ \\ a University of Nebraska-Lincoln, Department of Geosciences, 214 Bessey Hall, \\ Lincoln, NE 68588-0340, USA \\ b Duke University, Division of Earth and Ocean Sciences, Durham, NC 27708, USA \\ c Syracuse University, Department of Earth Sciences, Syracuse, NY 13210, USA \\ d Stanford University, Department of Geological and Environmental Sciences, \\ Stanford, CA 94305, USA \\ * Corresponding author P. M. Tapia, email ptapia@unlserve.unl.edu
}

\begin{abstract}
A composite high-resolution diatom stratigraphy from three piston cores and one box-core in the deep sub-basin of Lake Titicaca reveals large moisture variations during the past $30 \mathrm{kyr}$ in the Altiplano region. Diatom sequences indicate orbital and millennial-scale variability in water level and salinity. The pelagic freshwater diatom species Cyclotella andina and Cyclotella stelligera dominate Glacial-age sediments, suggesting that the lake was above its present outlet. Generally, wet conditions continued until 11,000 cal yr BP, as indicated by high percentages of freshwater planktonic diatoms. Large pulses of benthic diatom species between about 11,000 and 10,000 cal yr BP suggest brief intervals of largeamplitude declines in lake level. During the early Holocene (10,000-8,500 cal yr BP), a freshwater diatom assemblage suggests overflowing conditions. Pelagic freshwater diatoms are replaced ca. 8,500 cal yr BP by the salinity-indifferent species Cyclotella meneghiniana and by benthic taxa, indicating the beginning of lake regression. During the mid-Holocene (6,000-3,500 cal yr BP), the abundance of the saline taxon Chaetoceros muelleri, coupled with high abundances of epiphytic and epipelic diatoms, indicates maximum salinity and lowest lake levels in the entire 30,000 year record. Lake transgression began ca. 4,000 cal yr BP, and the lake achieved modern levels by about 1,500 cal yr BP. These water-level changes imply changes in effective moisture, most likely resulting from large precipitation changes. Precipitation was high throughout the Last Glacial Maximum $(21,000-18,000$ cal yr BP), likely due to an enhanced South American Summer Monsoon during peak summer insolation in the Southern Hemisphere. In contrast, the mid-Holocene transition was dryer than today in association with an austral summer insolation minimum and the subsequent weakening of the summer monsoon.
\end{abstract}

Keywords: paleoclimate, Last Glacial Maximum, mid-Holocene, tropical Andes, Lake Titicaca, South America, Quaternary, diatom biostratigraphy, lake level, precipitation 


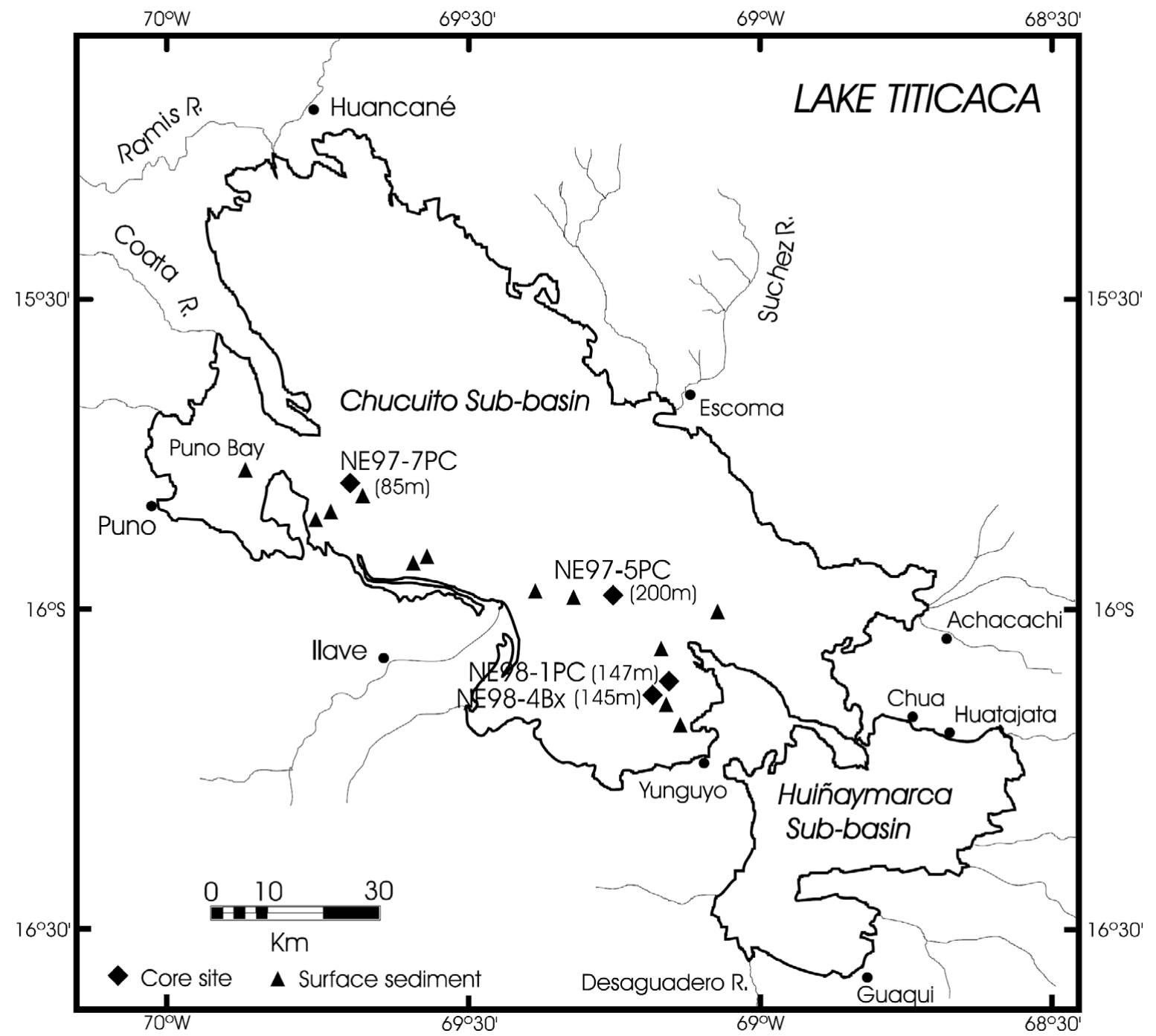

Figure 1. Distribution of cores and selected surface sediments in the Chucuito sub-basin, Lake Titicaca, Peru and Bolivia.

\section{Introduction}

Recent evaluations of the nature and timing of the Last Glacial Maximum (LGM) in the neotropics indicate temperature depression of $5-6{ }^{\circ} \mathrm{C}$ around 21 kyr BP, based on pollen (Bush et al., 1990), snowline depression (Seltzer, 1994), noble gases in groundwater (Stute et al., 1995), and modeling results using revised tropical sea-surface temperatures (Hostetler and Mix, 1999). However, currently no consensus exists regarding moisture conditions. Some studies suggest that the tropical Andes and Amazonia were wet at the LGM (Servant and Fontes, 1978; Haberle and Maslin, 1999; Colinvaux et al., 2000; Baker et al., 2001a; and Baker et al., 2001b), whereas other authors suggest that arid conditions prevailed (Clapperton, 1993; Van der Hammen and Asby, 1994; and Hooghiemstra and van der Hammen, 1998). In order to clarify paleoenvironments and the paleoclimatic variability in tropical South America, we investigated sediments from Lake Titicaca in the tropical Andes.

Lake Titicaca (Figure 1) is the highest (3,810 masl (meters above sea level)) large lake in the world and is located in the tropical Andes (northern Altiplano of Peru and Bolivia, $15^{\circ}-16^{\circ} 30^{\prime} \mathrm{S}, 68^{\circ} 30^{\prime}-70^{\circ} \mathrm{W}$ ). The lake contains two main sub-basins: Chucuito (also 
Table 1

Piston and box core locations and associated water depth from Lake Titicaca

\begin{tabular}{|c|c|c|c|c|}
\hline \multicolumn{5}{|l|}{ Piston cores } \\
\hline Sample ID & Lat. S & Long. W & $\begin{array}{r}\text { Water depth } \\
(\mathrm{m})\end{array}$ & $\begin{array}{r}\text { Core length } \\
(\mathrm{m})\end{array}$ \\
\hline NE97-5PC & 1558.878 & 6917.148 & 185 & \\
\hline NE97-7PC & 1548.384 & 6942.096 & 89 & 8.33 \\
\hline NE98-1PC & 1608.004 & 6909.199 & 152 & 10.6 \\
\hline \multicolumn{5}{|c|}{ Box cores and surface sediments } \\
\hline Sample ID & Lat. S & Long. W & $\begin{array}{r}\mathrm{Z} \\
(\mathrm{m})\end{array}$ & \\
\hline 04.VI.97-1 & 1553.265 & 6946.152 & 5.8 & \\
\hline 04.VI.97-2 & 1553.190 & 6945.999 & 10 & \\
\hline 04.VI.97-3 & 1553.099 & 6945.941 & 15 & \\
\hline 04.VI.97-4 & 1553.106 & 6945.962 & 15 & \\
\hline 04.VI.97-5 & 1553.096 & 6945.941 & 18 & \\
\hline 04.VI.97-6 & 1553.023 & 6945.896 & 25 & \\
\hline 04.VI.97-7 & 1552.678 & 6945.566 & 37 & \\
\hline 04.VI.97-8 & 1552.388 & 6945.455 & 45 & \\
\hline 05.VI.97-1 & 1556.807 & 6933.731 & 60 & \\
\hline 05.VI.97-2 & 1556.807 & 6933.731 & 60 & \\
\hline 05.VI.97-3 & 1556.060 & 6933.977 & 80 & \\
\hline 05.VI.97-4 & 1555.797 & 6933.567 & 100 & \\
\hline 05.VI.97-5 & 1555.000 & 6933.291 & 120 & \\
\hline 05.VI.97-6 & 1554.345 & 6933.167 & 140 & \\
\hline 08.VI.97-3 & 1601.971 & 6906.912 & 201 & \\
\hline NE98-1BX & 1605.530 & 6910.585 & 155 & \\
\hline NE98-2BX & 1610.538 & 6910.661 & 113 & \\
\hline NE98-3BX & 1608.743 & 6909.194 & 141 & \\
\hline NE98-4BX & 1608.259 & 6909.267 & 145 & 0.847 \\
\hline NE98-5BX & 1608.022 & 6909.293 & 146 & \\
\hline NE98-6BX & 1612.155 & 6906.600 & 4 & \\
\hline NE98-7BX & 1612.337 & 6906.732 & 29 & \\
\hline NE98-8BX & 1557.962 & 6923.070 & 72 & \\
\hline NE98-9BX & 1557.442 & 6926.331 & 146 & \\
\hline NE98-10BX & 1548.392 & 6942.117 & 90 & \\
\hline NE98-11BX & 1546.519 & 6952.040 & 29 & \\
\hline 61 & (Yunguyo Bay) & & 0.1 & \\
\hline 67 & (Yunguyo Bay) & & 1 & \\
\hline 84 & (Yunguyo Bay) & & 3.4 & \\
\hline 85 & (Yunguyo Bay) & & 4 & \\
\hline 86 & (Yunguyo Bay) & & 5 & \\
\hline 87 & (Yunguyo Bay) & & 5 & \\
\hline 100 & (Yunguyo Bay) & & 7 & \\
\hline 88 & (Yunguyo Bay) & & 20 & \\
\hline 101 & (Yunguyo Bay) & & 25 & \\
\hline
\end{tabular}

Data from Yunguyo Bay after Miskane (1992). The tops of the box cores were used as modern surface sediment samples.

called Lago Grande or Lago Mayor, mean depth $=135 \mathrm{~m}$, max. depth = $284 \mathrm{~m}$ ) and Huiñaymarca (Lago Pequeño or Lago Menor, mean depth $=9 \mathrm{~m}$, max. depth $=42 \mathrm{~m})$. These sub-basins are connected through the Strait of Tiquina (width = $850 \mathrm{~m}$ ), which contains a sill (3,788 masl, modern water depth = $22 \mathrm{~m}$ ) that separates the two sub-basins (Wirrmann, 1992). Another sill (3,804 masl, modern water depth $=6 \mathrm{~m}$ ) exists at the connection between the Huiñaymarca sub-basin and Lake Titicaca's only outlet, the 
Table 2

Phytoplankton, watershed sample locations, and Secchi depth measurements from Lake Titicaca and surrounding areas

\begin{tabular}{|c|c|c|c|c|c|c|}
\hline \multicolumn{4}{|l|}{ Phytoplankton } & \multirow{2}{*}{$\begin{array}{l}\text { Z water sample } \\
\text { (m) }\end{array}$} & \multirow{2}{*}{$\begin{array}{r}\text { Secchi depth } \\
\text { (m) }\end{array}$} & \multirow{2}{*}{$\begin{array}{r}\text { Net aperture } \\
(\mu \mathrm{m})\end{array}$} \\
\hline Sample ID & Lat. S & Long. W & $\begin{array}{r}\mathrm{Z} \\
(\mathrm{m})\end{array}$ & & & \\
\hline 15.V.96-1 & 1613.321 & 6908.802 & NA & (surface) & NA & 20 \\
\hline 15.V.96-2 & 1613.321 & 6908.802 & NA & (surface) & NA & 5 \\
\hline 18.V.96-1 & 1611.2 & 6909.8 & NA & (surface) & NA & 20 \\
\hline 18.V.96-2 & 1611.2 & 6909.8 & NA & (surface) & 5.5 & 5 \\
\hline 21.V.96-1 & 1515.516 & 6912.659 & NA & (surface) & NA & 20 \\
\hline 21.V.96-2 & 1515.516 & 6912.659 & NA & (surface) & NA & 5 \\
\hline 22.V.96-1 & 1531.906 & 6937.132 & NA & (surface) & NA & 5 \\
\hline 22.V.96-2 & 1531.906 & 6937.132 & NA & (surface) & NA & 20 \\
\hline 23.V.96-1 & 1522.468 & 6904.080 & 61 & NA & NA & 20 \\
\hline 23.V.96-2 & 1522.468 & 6904.080 & 61 & NA & NA & 5 \\
\hline 24.V.96-1 & 1549.590 & 6945.284 & 60 & NA & NA & 20 \\
\hline 24.V.96-2 & 1549.551 & 6945.182 & 60 & NA & NA & 5 \\
\hline 25.V.96-1 & 1602.609 & 6919.204 & 148 & NA & 8.5 & 20 \\
\hline 25.V.96-2 & 1602.609 & 6919.204 & 148 & NA & 8.5 & 5 \\
\hline 03.VI.97-1 & 1549.649 & 6944.952 & 64 & NA & 8.0 & 10 \\
\hline 05.VI.97-7 & 1554.950 & 6939.356 & 50 & NA & NA & 10 \\
\hline 05.VI.97-8* & 1554.950 & 6939.356 & 65 & 5 & NA & filter \\
\hline 05.VI.97-9* & 1554.950 & 6939.356 & 65 & 50 & NA & filter \\
\hline 05.VI.97-10 & 1550.533 & 6936.329 & 150 & NA & NA & 10 \\
\hline 05.VI.97-11* & 1550.584 & 6936.280 & 150 & 5 & NA & filter \\
\hline 05.VI.97-12* & 1550.584 & 6936.280 & 150 & 75 & NA & filter \\
\hline 05.VI.97-13 & 1539.322 & 6931.239 & 250 & NA & NA & 10 \\
\hline 05.VI.97-14* & 1539.322 & 6931.239 & 250 & 5 & NA & filter \\
\hline 05.VI.97-15* & 1539.322 & 6931.239 & 250 & 100 & NA & filter \\
\hline 06.VI.97-1 & 1531.185 & 6930.441 & 260 & NA & 8.5 & 10 \\
\hline 06.VI.97-2 & 1531.760 & 6931.989 & 255 & NA & 7.6 & 10 \\
\hline 06.VI.97-3 & 1532.812 & 6933.854 & 273 & NA & 7.0 & 10 \\
\hline 06.VI.97-4 & 1533.829 & 6939.090 & 265 & NA & 8.5 & 10 \\
\hline 06.VI.97-5 & 1534.654 & 6940.097 & 238 & NA & 8.5 & 10 \\
\hline 06.VI.97-6 & 1535.553 & 6943.301 & 200 & NA & 8.5 & 10 \\
\hline 06.VI.97-7 & 1546.828 & 6934.185 & 184 & NA & 6.5 & 10 \\
\hline 06.VI.97-8 & 1556.347 & 6925.751 & 168 & NA & 6.5 & 10 \\
\hline 07.VI.97-1 & 1607.841 & 6918.872 & 89 & NA & NA & 10 \\
\hline 07.VI.97-2* & 1607.841 & 6918.872 & 89 & 5 & NA & filter \\
\hline 07.VI.97-3* & 1607.841 & 6918.872 & 89 & 70 & NA & filter \\
\hline 07.VI.97-4 & 1559.917 & 6926.231 & 20 & NA & NA & 10 \\
\hline 07.VI.97-5* & 1559.917 & 6926.231 & 20 & 19 & NA & filter \\
\hline 07.VI.97-6 & 1559.984 & 6925.133 & 87 & NA & NA & 10 \\
\hline 07.VI.97-7 & 1559.337 & 6922.767 & 165 & NA & NA & 10 \\
\hline 07.VI.97-8 & 1557.049 & 6916.011 & 209 & NA & NA & 10 \\
\hline 08.VI.97-1 & 1601.971 & 6906.912 & 201 & NA & 8.9 & 10 \\
\hline 08.VI.97-2 & 1601.971 & 6906.912 & 201 & NA & 8.9 & 10 \\
\hline 08.VI.97-4 & 1612.4 & 6841.136 & NA & NA & 10 & \\
\hline 22.V.98-1 & 1605.530 & 6910.535 & 155 & NA & NA & NA \\
\hline 23.V.98-1 & 1610.497 & 6910.685 & 118 & NA & NA & NA \\
\hline 23.V.98-2 & 1614.885 & 69.08.217 & 3.3 & NA & NA & 10 \\
\hline 23.V.98-3 & 1614.586 & 6908.485 & 52 & NA & NA & 10 \\
\hline 23.V.98-4 & 1610.881 & 6910.592 & 101 & NA & NA & 10 \\
\hline 26.V.98-1 & 1557.447 & 6926.331 & 146 & NA & NA & NA \\
\hline 27.V.98-1 & 1548.390 & 6942.117 & 90 & NA & 15.5 & 10 \\
\hline 27.V.98-2 & 1546.519 & 6952.040 & 29 & NA & 9.0 & 10 \\
\hline 29.V.98-1 & 1612.4 & 6850.2 & NA & (surface) & NA & NA \\
\hline
\end{tabular}


Table 2 (Continued).

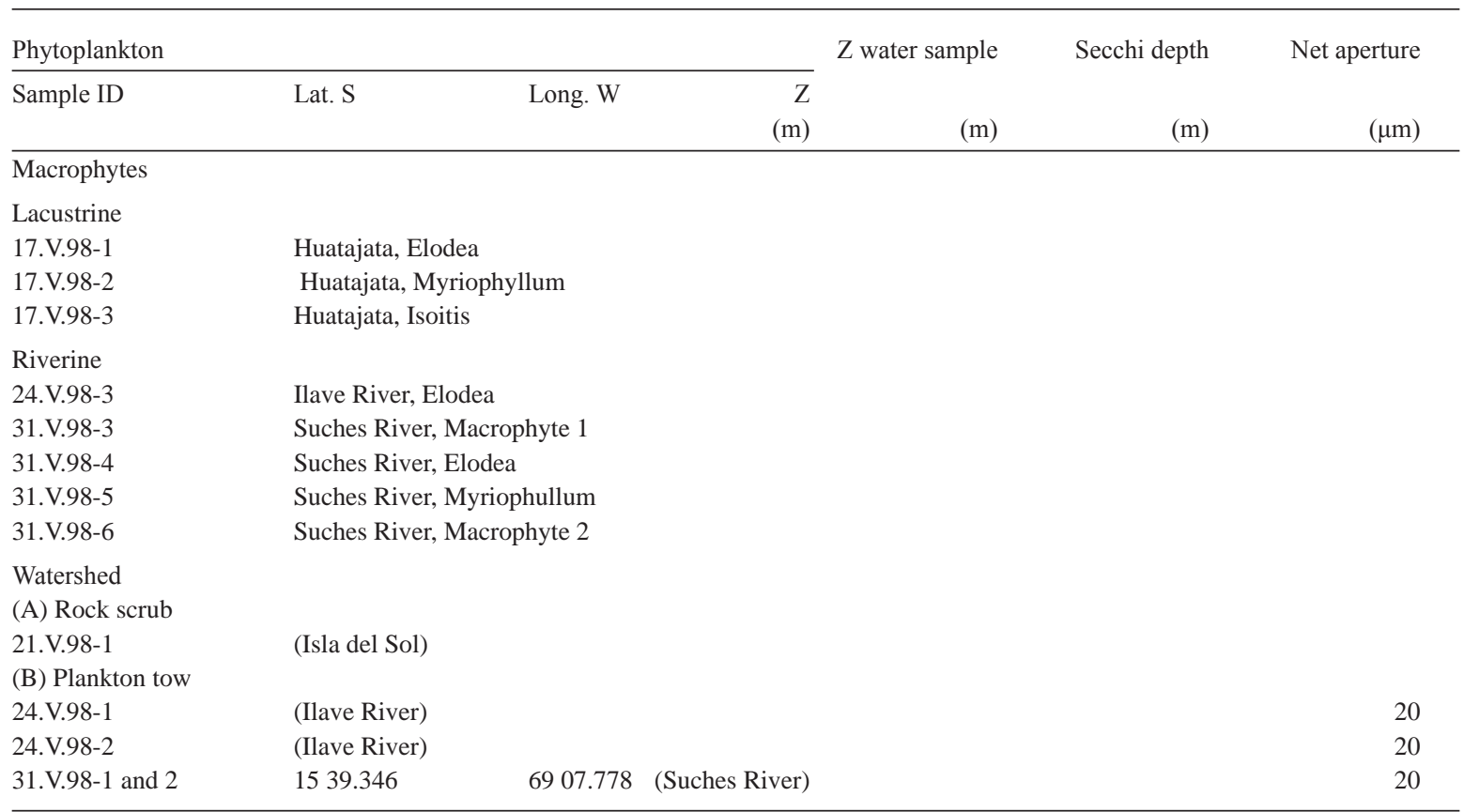

Asterisk denotes POM filter samples.

Desaguadero River; therefore overflowing conditions will exist if lake water levels are at or exceed the outlet sill height. The modern lake receives its water input through direct precipitation on the lake (47\%), mainly in the austral summer (DJF), and from rivers and streams (53\%). On average, about $91 \%$ of water is lost via evaporation and 9\% via the Desaguadero River, which connects Lake Titicaca with the saline shallow Lake Poopó in the central Altiplano (Roche et al., 1992).

Modern data indicate that the variance in precipitation is greater than that of evaporation, so variations in lake level depend mainly on the amount of precipitation that reaches the basin (Baker et al., 2001a). Lake Titicaca has not been influenced directly by late-Quaternary glaciation, and therefore the lake contains a continuous record of late-Quaternary sedimentation in the deeper part of the ba$\sin$. Because the precipitation that reaches the lake is derived from the Amazon basin (Lenters and Cook, 1997), this quasi-endorheic system has the potential to register Amazonian paleoclimate and to be used as a template for continental climatic evolution in the southern tropics of South America.
Here we report the late-Quaternary diatom record from the deep-water sub-basin of Lake Titicaca and interpret the associated climatological changes in the Altiplano region during the past 30,000 years.

\subsection{Climate in the Central Andes}

Modern tropical South American climate is controlled by a complex system that includes the annual march of the Intertropical Convergence Zone (ITCZ), the position and strength of the Bolivian High, the presence of the Andes as an effective orographic barrier, the South Atlantic Convergence Zone, and the South Pacific High (SPH). Most of the precipitation in the Central Andes occurs during the austral summer (DJF). Moisture from the Amazonian basin is advected into the Central Andes, when summer heating creates unstable air aloft. The uplifted warm saturated air condenses at higher altitude, producing rainfall on the eastern slope of the Andes and on the Altiplano. Wet (dry) episodes are related to anticyclonic (cyclonic) anomalies and are accompanied by easterly (westerly) wind anomalies (Garreaud, 1999). The upper troposphere warm- 
core anticyclone centered in the Northern Altiplano is called the Bolivian High (BH) and persists during summertime. The intensity and locus of the $\mathrm{BH}$ is correlated with the latitudinal displacement of the ITCZ over South America (Lenters and Cook, 1997).

\section{Material and methods}

Selected samples from three piston (NE97-5PC, NE97-7PC, NE98-1PC) cores and one box (NE98$4 \mathrm{BXB}$ ) core (Figure 1) were processed for siliceous microfossil analysis. We analyzed 286 levels at 4$20 \mathrm{~cm}$ intervals in the three cores. The cores present variable sediment accumulation rates from 16 to 95 $\mathrm{cm} \mathrm{ka}^{-1}$, therefore the samples resolve centennial to millennial episodes.

To investigate modern spatial distribution of benthic and pelagic diatoms, 26 surface-sediment samples were processed from the top of box cores throughout the Lake Titicaca basin (Table 1). Additionally, results from nine surface-sediment samples from a previous study in the Yunguyo Bay area of the lake were added to this profile (Miskane, 1992). Additional data on modern diatom ecological distribution in the lake water column, littoral zone, and immediate watershed streams were attained with 55 plankton-tow, eight macrophyte, and one rock-scrub samples (Table 2). The lacustrine phytoplankton samples include 43 vertical plankton tows (upper 30 $\mathrm{m}$ in deep waters, less in shallow areas) using plankton nets of variable apertures $(5,10$, and $20 \mu \mathrm{m})$ and nine filters of particulate organic matter (POM). Additionally, three riverine horizontal plankton-tow samples were collected from the Ilave River, Peru and the Suches River, Bolivia. Macrophyte samples are both lacustrine (Inca Utama Pier in Huatajata, Bolivia) and riverine (Ilave River, Suches River) in origin. One rock-scrub sample from Inca spring, Isla del Sol, Bolivia, contained both brown mucilage and Sphagnum leaves.

Forty-five accelerator mass spectrometry (AMS) radiocarbon dates from bulk organic carbon (Table 3) were used to establish the chronology in the four cores. ${ }^{14} \mathrm{C}$ ages were transformed into calendar ages using INTCAL98 for ages less than $24 \mathrm{kyr}$
(Stuiver et al., 1998) and the calibration curve of Bard (1998) for older ages (Baker et al., 2001a). The chronological sequence and age model (Figure 2) were established using linear interpolation between calibrated ${ }^{14} \mathrm{C}$ calendar ages. Additional geochronological data and age models are found in Rowe et al. (2002) and Seltzer et al. (2002, supplemental data).

Core, surface-sediment, and modern samples were treated with cold $\mathrm{HCl}$ and $\mathrm{H}_{2} \mathrm{O}_{2}$ following Battarbee (1986). Quantitative estimates of microfossil concentration in core sediments were made with polystyrene microspheres (Battarbee and Kneen, 1982). Slides were mounted in Naphrax ${ }^{\circledR}$ (R.I. 1.74), and diatoms were counted at a magnification of $1,000 \times$ (objective $100 \times$, N.A. 1.30) in a Leica DMRX transmitted-light microscope with differential interference contrast. A minimum of 300 diatom valves for fossil samples and 400 valves for modern samples were counted in each slide. In intervals where the minimum amount was not reached within 10 scanned parallel traverses, because of extremely low diatom abundance or intense silica diagenesis, the percent and absolute abundances were not calculated. Chrysophyte statocysts and sponge spicules were counted, and their abundance is expressed as a percentage relative to the total number of diatom valves. Diatom counts were transformed to both relative (\%) and absolute (million valves/g wet-sediment) abundances.

Diatom diagrams were generated using Tilia, Tiliagraph, and Tiliagraph-View software (Eric Grimm, Illinois State Museum) and include species present at $>5 \%$ relative abundance in one or more core depths. Local diatom biostratigraphic zones in Lake Titicaca are proposed based on the relative abundance of one or more representative planktonic diatom species, as observed in the compiled core NE98-4BxB/NE981PC, and NE97-7PC. These visually distinctive diatom zones were adjusted and subdivided following main groups within the stratigraphically constrained cluster analysis, CONISS (Grimm, 1987), using the dissimilarity method of Edwards and Cavalli-Sforza's cord distance (square-root transformed) to account for lower abundances. Diatom identification was based on common floras (Krammer and Lange-Bertalot, 1991-2000; Lange-Bertalot et al., 1996; Hustedt, 
Table 3

${ }^{14} \mathrm{C}$ and calibrated ages from selected samples in four cores from Lake Titicaca

\begin{tabular}{|c|c|c|c|c|c|c|}
\hline Core & Sample & $\begin{array}{l}\text { Depth below } \\
\text { water-sed. } \\
\text { interface }(\mathrm{m})\end{array}$ & Sample type & $\begin{array}{c}\text { Radiocarbon } \\
\text { age } \\
\left({ }^{14} \mathrm{C} \text { yr BP }\right)\end{array}$ & $\begin{array}{l}\text { Age error } \\
\text { (1 S.D.) }\end{array}$ & $\begin{array}{c}\text { Calibrated } \\
\text { age } \\
\text { (cal yr BP) } \\
\end{array}$ \\
\hline \multirow[t]{12}{*}{ NE97-5PC } & Sect. 5, $0.07 \mathrm{~m}$ & 3.25 & Bulk organic matter & 7,840 & 130 & 8,599 \\
\hline & Sect. 5, $0.57 \mathrm{~m}$ & 3.75 & Bulk organic matter & 9,820 & 80 & 11,201 \\
\hline & Sect. 5, $0.97 \mathrm{~m}$ & 4.15 & Bulk organic matter & 11,270 & 55 & 13,171 \\
\hline & Sect. 5, $1.16 \mathrm{~m}$ & 4.34 & Bulk organic matter & 11,980 & 55 & 13,896 \\
\hline & Sect. $4,0.00 \mathrm{~m}$ & 4.74 & Bulk organic matter & 14,110 & 70 & 16,916 \\
\hline & Sect. 4, $0.10 \mathrm{~m}$ & 4.84 & Bulk organic matter & 16,400 & 95 & 19,551 \\
\hline & Sect. $4,0.40 \mathrm{~m}$ & 5.14 & Bulk organic matter & 16,570 & 120 & 19,747 \\
\hline & Sect. 4, $0.80 \mathrm{~m}$ & 5.54 & Bulk organic matter & 20,220 & 110 & 23,947 \\
\hline & Sect. 4, $1.12 \mathrm{~m}$ & 5.86 & Bulk organic matter & 20,830 & 190 & 24,550 \\
\hline & Sect. 3, $0.60 \mathrm{~m}$ & 6.86 & Bulk organic matter & 21,900 & 170 & 5,792 \\
\hline & Sect. 2, $1.22 \mathrm{~m}$ & 9.04 & Bulk organic matter & 24,430 & 190 & 28,702 \\
\hline & Sect. 1, $1.39 \mathrm{~m}$ & 10.74 & Bulk organic matter & 25,300 & 200 & 29,694 \\
\hline \multirow[t]{13}{*}{ NE97-7PC } & Sect. 6, $0.52 \mathrm{~m}$ & 0.52 & Bulk organic matter & 2,630 & 25 & 2,757 \\
\hline & Sect. 5, $1.5 \mathrm{~m}$ & 2.39 & Bulk organic matter & 5,300 & 50 & 6,088 \\
\hline & Sect. 4, $0.55 \mathrm{~m}$ & 3 & Bulk organic matter & 5,630 & 60 & 6,394 \\
\hline & Sect. 4, $0.55 \mathrm{~m}$ & 3 & Carbonate & 5,400 & 40 & 6,226 \\
\hline & Sect. 3, $0.39 \mathrm{~m}$ & 4.205 & Bulk organic matter & 8,450 & 50 & 9,481 \\
\hline & Sect. 3, $0.80 \mathrm{~m}$ & 4.615 & Bulk organic matter & 10,080 & 85 & 11,612 \\
\hline & Sect. 3, $1.20 \mathrm{~m}$ & 5.015 & Bulk organic matter & 10,640 & 70 & 12,718 \\
\hline & Sect. 2, $0.12 \mathrm{~m}$ & 5.505 & Bulk organic matter & 11,760 & 60 & 13,813 \\
\hline & Sect. 2, $0.32 \mathrm{~m}$ & 5.705 & Bulk organic matter & 12,610 & 60 & 14,593 \\
\hline & Sect. 2, $0.62 \mathrm{~m}$ & 6.005 & Bulk organic matter & 13,300 & 85 & 16,043 \\
\hline & Sect. 2, $0.82 \mathrm{~m}$ & 6.205 & Bulk organic matter & 14,150 & 95 & 17,277 \\
\hline & Sect. 2, $0.97 \mathrm{~m}$ & 6.355 & Bulkorganic matter & 12,950 & 155 & 15,579 \\
\hline & Sect. 1, $1.08 \mathrm{~m}$ & 8 & Bulk organic matter & 17,200 & 95 & 20,682 \\
\hline \multirow[t]{5}{*}{ NE98-4BXB } & $0 \mathrm{~m}$ & 0 & Bulk organic matter & 0 & 0 & 0 \\
\hline & $0.30 \mathrm{~m}$ & 0.3 & Bulk organic matter & 1,490 & 45 & 1,366 \\
\hline & $0.60 \mathrm{~m}$ & 0.6 & Bulk organic matter & 2,370 & 40 & 2,357 \\
\hline & $0.83 \mathrm{~m}$ & 0.83 & Bulk organic matter & 3,490 & 40 & 3,765 \\
\hline & $0.83 \mathrm{~m}$ & 0.83 & Humin extract & 3,850 & 40 & 4,252 \\
\hline \multirow[t]{19}{*}{ NE98-1PC } & Sect. $7,0.30 \mathrm{~m}$ & $0.745(1.428)$ & Bulk organic matter & 5,550 & 55 & 6,311 \\
\hline & Sect. 7, $0.56 \mathrm{~m}$ & $1(1.683)$ & Bulk organic matter & 5,820 & 50 & 6,651 \\
\hline & Sect. 7, $0.90 \mathrm{~m}$ & $1.345(2.028)$ & Bulk organic matter & 7,240 & 75 & 8,025 \\
\hline & Sect. 7, $1.28 \mathrm{~m}$ & 1.71 (2.393) & Bulk organic matter & 8,830 & 45 & 9,897 \\
\hline & Sect. $7,1.44 \mathrm{~m}$ & $1.88(2.563)$ & Bulk organic matter & 9,340 & 50 & 10,557 \\
\hline & Sect. 7, $1.50 \mathrm{~m}$ & $1.945(2.628)$ & Bulk organic matter & 10,050 & 85 & 11,499 \\
\hline & Sect. 6, $0.15 \mathrm{~m}$ & $2.16(2.843)$ & Bulk organic matter & 10,400 & 70 & 12,337 \\
\hline & Sect. $6,0.40 \mathrm{~m}$ & 2.41 (3.093) & Bulk organic matter & 10,970 & 55 & 12,988 \\
\hline & Sect. 6, $0.50 \mathrm{~m}$ & 2.51 (3.193) & Bulk organic matter & 11,250 & 55 & 13,166 \\
\hline & Sect. $6,0.70 \mathrm{~m}$ & 2.715 (3.398) & Bulk organic matter & 12,810 & 60 & 15,448 \\
\hline & Sect. 6, $0.84 \mathrm{~m}$ & 2.855 (3.538) & Bulk organic matter & 13,350 & 90 & 16,041 \\
\hline & Sect. 6, $1.03 \mathrm{~m}$ & $3.04(3.723)$ & Bulk organic matter & 14,350 & 65 & 17,192 \\
\hline & Sect. 6, $1.04 \mathrm{~m}$ & 3.055 (3.738) & Bulk organic matter & 14,700 & 85 & 17,595 \\
\hline & Sect. 5, $0.40 \mathrm{~m}$ & 3.545 (4.228) & Bulk organic matter & 15,850 & 90 & 18,918 \\
\hline & Sect. $5,0.60 \mathrm{~m}$ & 3.745 & Bulkorganic matter & 17,200 & 170 & 20,472 \\
\hline & Sect. 5, $0.80 \mathrm{~m}$ & 3.945 (4.628) & Bulk organic matter & 16,700 & 100 & 19,896 \\
\hline & Sect. 4, $0.20 \mathrm{~m}$ & $4.545(5.228)$ & Bulk organic matter & 18,900 & 170 & 22,428 \\
\hline & Sect. 3, $0.30 \mathrm{~m}$ & $6.185(6.868)$ & Bulk organic matter & 20,900 & 190 & 24,632 \\
\hline & Sect. 2, $0.60 \mathrm{~m}$ & $8.045(8.728)$ & Bulk organic matter & 23,400 & 250 & 27,522 \\
\hline
\end{tabular}

Bold areas indicate sample and ages excluded from interpolation calculations. 
LAKE TITICACA - AGE MODEL

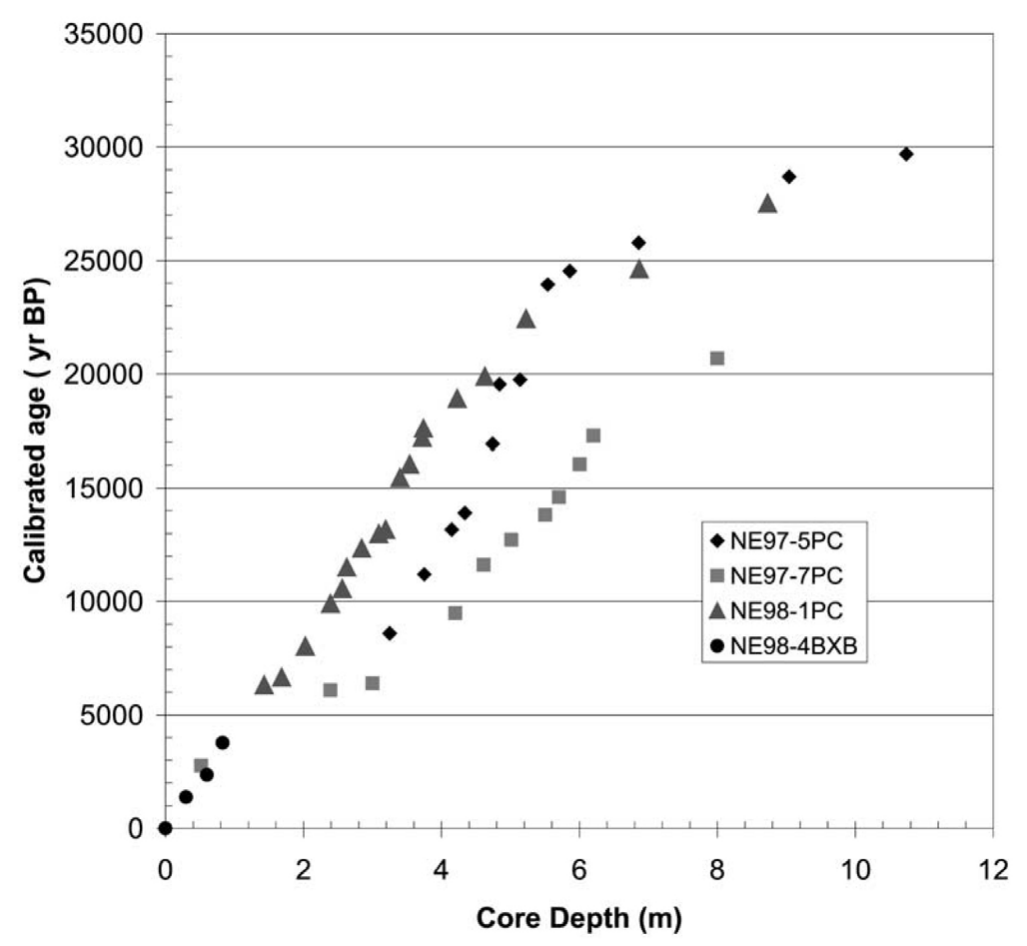

Figure 2. Lake Titicaca age model from four cores described in the text.

1930; Hustedt, 1930-1966; Simonsen, 1987; Patrick and Reimer, 1966-1975; Germain, 1981; Reichardt, 1995; and Schmidt et al., 1874-1959) and regional studies (Hustedt, 1927; Iltis et al., 1984; Frenguelli, 1929; Frenguelli, 1934; Frenguelli, 1936; Frenguelli, 1939; Manguin, 1964; Metzeltin and Lange-Bertalot, 1998; Patrick, 1961; Rumrich et al., 2000; ServantVildary, 1978a; Servant-Vildary, 1978b; ServantVildary, 1984; Servant-Vildary, 1986; and ServantVildary and Blanco, 1984).

\section{Results}

\subsection{Core NE97-7PC}

Piston core NE97-7PC is $8.28 \mathrm{~m}$ long; it extends from the late Holocene to the LGM ( $\sim 1900$ to $21,000 \mathrm{cal}$ yr BP) on the basis of 13 AMS calendar radiocarbon ages (Table 3 ). The age model suggests average sedimentation rates from $67 \mathrm{~cm}$ $\mathrm{ka}^{-1}$ for the top $3 \mathrm{~m}$ to $35 \mathrm{~cm} \mathrm{ka}^{-1}$ for the rest of the core. Sample spacing is about $500 \mathrm{cal}$ yr. Two radiocarbon dates were excluded from the age model, because of the sample material (carbonate, sample level $3 \mathrm{~m}$ ) or because of an age reversal $(6.355 \mathrm{~m}$ ). Sediments in the upper $2.69 \mathrm{~m}$ of the core are composed of very dark gray-brown, non-calcareous, homogeneous silt with sparsely distributed gastropods below $0.65 \mathrm{~m}$. Diatom stratigraphy (Figure 3) in the upper section (zone C6) is characterized by low abundances of Cyclotella andina and Cyclotella stelligera and moderate percentages of Cyclotella meneghiniana. This is followed by a zone (C5) dominated by C. meneghiniana ( 90\%) and an assemblage of several benthic taxa, which are present at $20 \%$ or less of total counts. The saline planktonic species Chaetoceros muelleri increases below $1.0 \mathrm{~m}$ up to $30 \%$ (C4). The diatom C. meneghiniana decreases its dominance at the zone C4/C3 transition, whereas the epipsammic taxon Pseudostaurosira zeilleri increases (up to $35 \%$ ), as well other benthic 
and epiphytic taxa. A gradational change downcore to lighter dark-grayish-brown silt with sparse gastropods and a calcareous matrix occurs from 2.69 to $3.79 \mathrm{~m}$ (zone C1 and part of C2). C. muelleri declines in zone $\mathrm{C} 2$, whereas a peak of the epiphytic taxon Tabularia tabulata (40\%) and other benthic taxa (up to 60\%) occurs in this interval. Downcore (zone C1) C. meneghiniana continues to decrease in relative abundance and the freshwater planktonic taxa $C$. stelligera-complex increases. At the base of this zone, $C$. andina reappears. The section between 3.79 and 5.36 m (zone B3 and part of B2) is composed of homogeneous, very dark gray-brown silty clay with sparse gastropods. The diatom assemblage is dominated in zone B3 by C. andina (up to 85\%), with low abundances of $C$. stelligera-complex, and a peak of shallow-water benthic diatom association (up to 65\%). C. stelligera-complex increases in zone B2. A peak of Aulacoseira granulata ( 15\%) occurs at $4.99 \mathrm{~m}$. Sediments from 5.36 to $6.78 \mathrm{~m}$ (lower B2 to middle B1) are homogeneous, sulfidebearing, dark-gray silty clay. Faint, cm-scale laminations occur between 6.36 and $6.40 \mathrm{~m}$. The dominant diatom in this interval is C. andina (up to $80 \%$ ), and benthic taxa comprise $10-40 \%$ of the assemblage. The interval from 6.78 to $8.28 \mathrm{~m}$ (lower part of zone B1) is characterized by sulfide-bearing, dark-grayish brown silty clay, with a pinkish tone, and faint cm-scale laminae. The diatom assemblage is dominated by C. andina (up to $65 \%$ ), although there are several levels in which benthic taxa are present up to $30 \%$, together with small percentages of C. meneghiniana (up to $30 \%$ ).

Diatom concentration varies from 3 to $66 \times 10^{6}$ valves per gram of wet sediment, and the sediments contain a relatively high diversity of 122 species, varieties, and formae. Two samples (4.59 and $6.76 \mathrm{~m}$ ) were not graphed because of low diatom abundances.

\subsection{Cores NE98-4BXB and NE98-1PC}

The complementary cores NE98-1PC (10.345 m long) and NE98-4BxB (0.847 m long), termed core 1PC-4Bx from now on, contain the most complete record in the Lake Titicaca deep basin (Figure 4). Box core NE98-4BXB spans an age range from 0 to 3,700 cal yr BP, based on four AMS radiocarbon ages (Table 3 ), yielding an average sedimentation rate of $22 \mathrm{~cm} \mathrm{ka}^{-1}$ and a sample resolution of $\sim 200$ cal yr. We excluded the humin extract datum at $0.83 \mathrm{~m}$ to standardize ages using the same sample type (bulk organic carbon). Sediments are composed of silt and clays, with finely laminated, carbonate-bearing layers toward the base. Dominant diatoms in the first $0.25 \mathrm{~m}$ of the core (zone C6) are Cyclotella andina and the Cyclotella stelligera-complex (80\%). Downward, this assemblage shifts to a dominance of Cyclotella meneghiniana (up to $85 \%$ ) towards the lower $0.73 \mathrm{~m}$ of the core (zone C5). In the lowest two samples of the box core $(0.77$ and $0.81 \mathrm{~m}$, reassigned depths as 0.8115 and $0.8714 \mathrm{~m}$-see below), Chaetoceros muelleri is subdominant (about 15\%, zone C4). Benthic diatoms, chrysophyte cysts, and sponge spicules are rare throughout the entire core. Diatom concentration varies from 6 to $51 \times 10^{6}$ valves per gram of wet sediment. Three samples $(0.41,0.47$, and 0.49 $\mathrm{m})$ were excluded from plots because of low diatom abundances. The base of box core NE98-4BxB was joined to the underlying top of piston core NE981PC based on their overlapping chronology. Thus, the sample NE98-1PC-8-1 that corresponds to the core depth of $1 \mathrm{~cm}$ was reassigned to a compiled depth of $0.693 \mathrm{~m}$.

Piston core NE98-1PC spans the late Holocene to the late Pleistocene $(\sim 2,900-31,200$ cal yr BP) on the basis of 19 AMS radiocarbon dates (Table 3). The core has average sedimentation rates from 24 $\mathrm{cm} \mathrm{ka}^{-1}$ for the interval between 0.683 and $5.228 \mathrm{~m}$ to $69 \mathrm{~cm} \mathrm{ka}^{-1}$ for the rest of the core; sample resolution varies from about 170 to $290 \mathrm{cal}$ yr. One radiocarbon date was excluded because of an age reversal (4.428 m, compiled core depth). Sediments from 0.683 to $0.838 \mathrm{~m}$ are massive non-calcareous darkgray silt. A sharp contact below $0.838 \mathrm{~m}$ marks the beginning of sub-millimeter calcareous dark-olive and white laminae, which extend to $1.428 \mathrm{~m}$. From 1.428 to $1.833 \mathrm{~m}$, the sediments are calcareous, greenish-gray silts with occasional laminae. The dominant diatom at the interval 0.683-1.833 m (Figure 4, zones C4, C3, C2, and C1) is C. meneghiniana (up to 95\%). C. muelleri has abundances up to $60 \%$ (zones C4 and C3), whereas the benthic taxa 


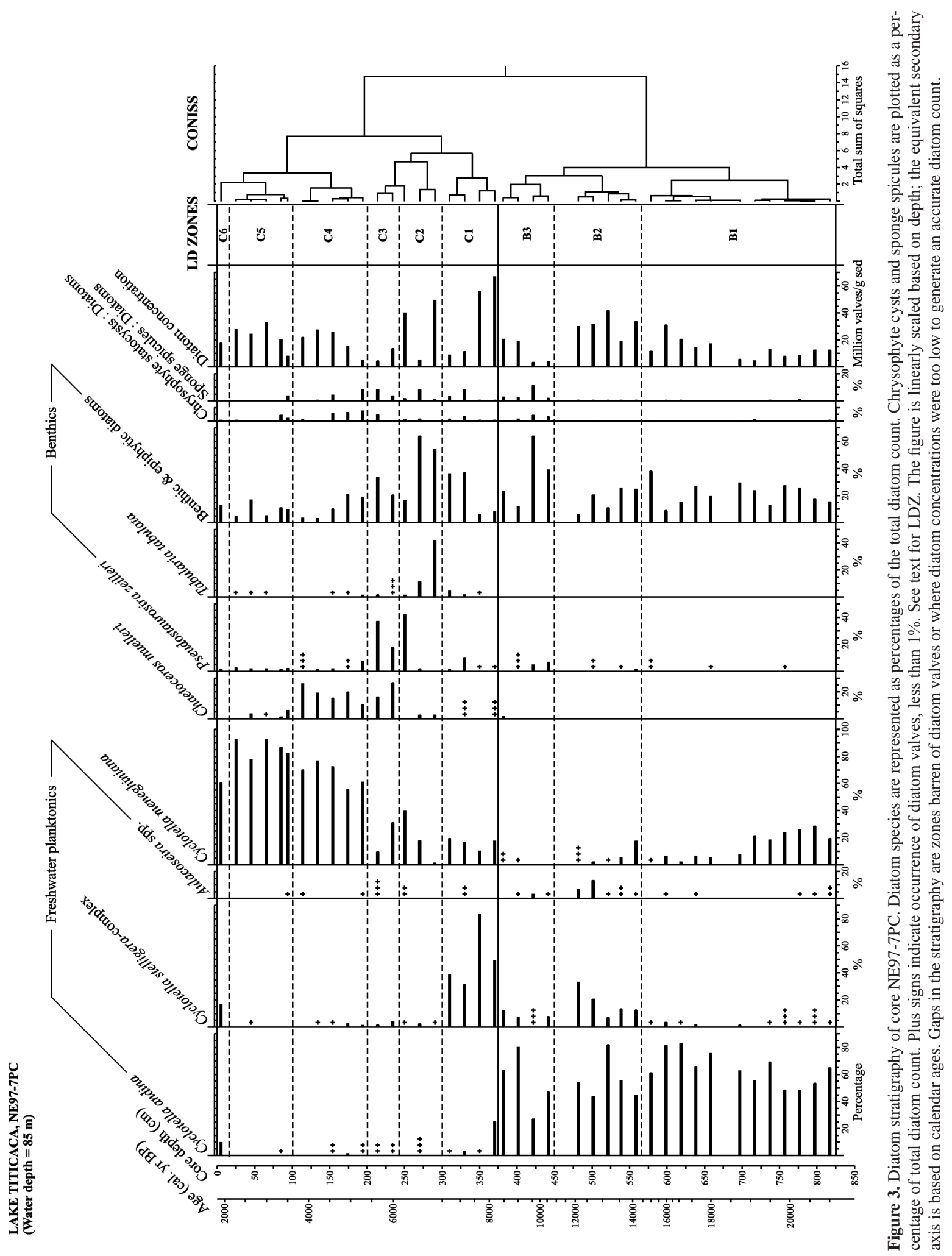


have high abundances (up to 95\%) in zones C3 and C2. The freshwater taxa C. stelligera-complex reappeared in zone C1. Between 1.833 and $2.393 \mathrm{~m}$, sediments contain massive dark greenish-gray silt with occasional gastropods and ostracod carapaces. A zone of massive very dark-gray clay occurs from 2.393 to $2.673 \mathrm{~m}$ and the following $2.5 \mathrm{~cm}$ is darkolive brown silt. In the interval from 1.833 to 2.693 $\mathrm{m}$ (zone B3), the freshwater taxon C. andina is dominant (up to 95\%), followed by benthic taxa with several abundance peaks throughout this interval. Between 2.693 and $3.143 \mathrm{~m}$, sediments are massive, non-calcareous, very dark-gray to greenish-gray clays with black reduced zones. A gradational contact occurs from 3.143 to $3.823 \mathrm{~m}$, giving rise to massive, organic-rich, non-calcareous olivegray to gray silt extending to $5.023 \mathrm{~m}$. The dominant diatom in the interval from 2.693 to $5.023 \mathrm{~m}$ (zones B2 and B1) is C. andina. C. stelligera-complex increases its relative abundance from 5 to $40 \%$ in zone B2, whereas Aulacoseira spp. has a peak in the upper part of this interval. At the transition to zone A2, Fragilaria crotonensis reaches $40 \%$ in relative abundance. Massive, non-calcareous, pinkish dark-gray silts, with some levels of sulfide-bearing sediments and gypsum rosettes, characterize an extended interval from 5.023 to $11.023 \mathrm{~m}$ (zones A2 and A1). Zones A2 and A1 are dominated by C. andina and the C. stelligera-complex. F. crotonensis occurs in zone A2, together with C. meneghiniana. A thick layer of volcanic ash dated at 27,500 cal yr $\mathrm{BP}$, by bracketing ${ }^{14} \mathrm{C}$ dates, occurs between 8.733 and $8.823 \mathrm{~m}$. Diatom concentration varies from 1 to $71 \times 10^{6}$ valves per gram of wet sediment. Several samples were excluded from plotting because they contained low abundances of diatoms (1.168-1.208 m, 1.328-1.408 m, 2.608 m, 3.378-3.418 m, 3.538$3.578 \mathrm{~m}, 3.908-4.388 \mathrm{~m}, 4.548 \mathrm{~m}, 5.038-5.988 \mathrm{~m}$, 6.228-6.308 m, $7.608 \mathrm{~m}, 8.008 \mathrm{~m}, 8.208 \mathrm{~m}, 8.528$ m, 9.328-9.408 m, and 10.478-10.798 m).

\subsection{Core NE97-5PC}

Piston core NE97-5PC is $10.7 \mathrm{~m}$ long; it extends from late-glacial to full glacial times $(\sim 12,000-$
29,500 cal yr BP), as suggested by combined biostratigraphic and radiocarbon dates (Table 4). We did not apply the complete radiocarbon chronology (Table 3, Figure 2) because date estimation by linear extrapolation in the top $3.25 \mathrm{~m}$ caused large deviations in comparison with cores NE97-7PC and NE98-1PC. We applied the estimated ages from the biostratigraphic range of Local Diatom Zones (LDZ) B2, B1 and A1 derived from the other cores (see below), and combined them with the last three radiocarbon dates to establish a continuous chronology. This new age model indicates average sedimentation rates from $50 \mathrm{~cm} \mathrm{ka}^{-1}$ for the top $4.5 \mathrm{~m}$ to $122 \mathrm{~cm} \mathrm{ka}^{-1}$ for the rest of the core; average sample resolution is ca. $200 \mathrm{cal}$ yr.

The upper $0.85 \mathrm{~m}$ of the sediment is composed of dark olive-gray homogeneous clay. From 0.85 to $1.65 \mathrm{~m}$, the sediments are alternating dark-olivegray and dark-green clay with cm-scale laminations. Diatom stratigraphy in the upper $1.65 \mathrm{~m}$ (zone B2, Figure 5) reveals a dominance of the deep freshwater species Cyclotella andina and a peak of the freshwater diatom Aulacoseira granulata in the core top, whereas Cyclotella stelligera has a significant peak at about $1.25 \mathrm{~m}$. The interval between 1.65 and $3.21 \mathrm{~m}$ is sulfide-bearing and is dark gray, alternating with black, cm-scale laminated silty-clay. From 3.21 to $4.21 \mathrm{~m}$, a gradational transition occurs from the unit above to lighter, homogeneous darkgrayish-brown clay. The dominant diatom throughout the interval from 1.65 to $4.21 \mathrm{~m}$ (lower zone B2 and zone B1) is C. andina. Cyclotella meneghiniana is common in zone B1. From 4.21 to $5.74 \mathrm{~m}$, the sediments are homogeneous, pinkish, dark-brown silty clay with low sulfide content. A dark-brown to grayish-brown clay transitional interval develops from 5.74 to $6.26 \mathrm{~m}$. The interval from 6.26 to 9.35 $\mathrm{m}$ is dominated by homogeneous grayish-brown silty clay with faint cm-scale laminations in the bottom meter; it also contains two ash layers (8.098.10 and $8.12-8.13 \mathrm{~m}$ ) and black sulfide nodules in the bottom $10 \mathrm{~cm}$. Dominant diatoms in the interval from 5.0 to $9.35 \mathrm{~m}$ (upper two-thirds of zone A1) are the planktonic species C. andina, C. stelligera, and C. meneghiniana. Throughout this interval, benthic diatoms contribute about $10 \%$ or less to the to- 


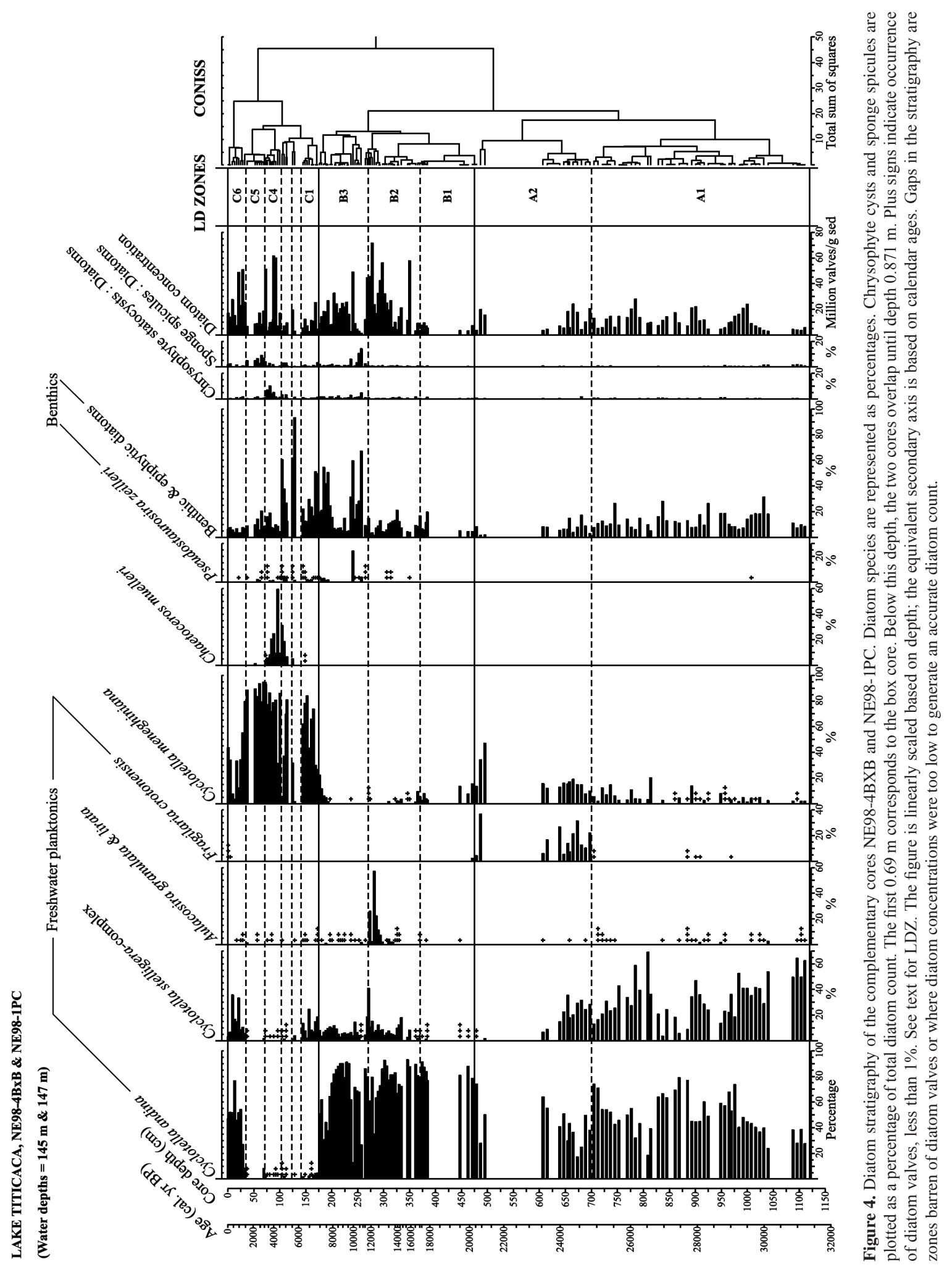


tal count, except in one interval centered at $6.50 \mathrm{~m}$, where benthic diatoms comprise slightly over $20 \%$. From 9.35 to $10.7 \mathrm{~m}$ (lower third of zone A1), the sediments are dominated by homogeneous, darkgray silty clay with infrequent black, sulfide nodules. Diatom stratigraphy is similar to the overlying interval. Throughout the core, total diatom concentration varies from 3 to $143 \times 10^{6}$ valves per gram of wet sediment. The sediments contain relatively low diatom diversity, with 55 species, varieties, and formae. Samples that were barren of diatoms or contained low abundances occurred at levels 2.0-2.4 m, 4.28-4.94 m, 5.54-5.74 m, and $8.52 \mathrm{~m}$.

\subsection{Local Diatom Zones (LDZ)}

The following local biostratigraphic zones are based on major diatom species abundance shifts from cores 1PC-4Bx and NE97-7PC and compared with stratigraphically constrained cluster analysis (Figure 3 and Figure 4).

\subsubsection{LDZ-A ( 31,500-20,500 cal yr BP)}

LDZ-A is present in NE98-1PC from 11.2 to 4.75 $\mathrm{m}$, and is characterized by the co-dominance of the freshwater species Cyclotella andina and Cyclotella stelligera-complex (Figure 4).

3.4.1.1. Subzone A1 The stratigraphic interval from the bottom of piston core NE98-1PC to core level 7.0 m ( 31,500-25,000 cal yr BP). This subzone contains high abundances of the two main Cyclotella species that define LDZ-A, low abundances of $C$. meneghiniana, and variable amounts (usually $<20 \%$ ) of benthic species. This subzone is also present in the bottom 5.5 m of core NE97-5PC (Figure 5).

3.4.1.2. Subzone A2 The interval from the top of subzone A1 to $4.75 \mathrm{~m}$ in NE98-1PC ( 25,00020,500 cal yr BP). The main feature of this subzone is the appearance of Fragilaria crotonensis. Although an incomplete subzone, because of an extended zone barren of diatoms, it is inferred that $C$. andina is dominant, $C$. stelligera decreases from the lower third of the subzone, and $C$. meneghiniana is more abundant. The benthic flora is below $20 \%$.

\subsection{2. $L D Z-B(\sim 20,500-7,000$ cal yr BP)}

LDZ-B is present in NE98-1PC from 4.75 to $1.75 \mathrm{~m}$ and is dominated by C. andina. Based on the short range and abundances of accompanying planktonic species, we divided this into three subzones (Figure 4).

3.4.2.1. Subzone B1 The stratigraphic interval from the top of subzone A2 to $3.7 \mathrm{~m}$ in core NE98-1PC ( 20,500-17,000 cal yr BP). The characteristic of this subzone is the near-absence of the $C$. stelligera-complex. A more continuous record is found in core NE97-7PC (Figure 3), which registers higher abundances of $C$. meneghiniana (up to $30 \%$ ) in the lower third of this subzone. We assigned this zonation in core NE97-5PC based on assemblage correlation (Figure 5).

3.4.2.2. Subzone B2 The interval from the top of subzone B1 to $2.7 \mathrm{~m}$ in NE98-1PC ( 17,000-11,500 cal yr BP). In this interval, C. stelligera-complex becomes more abundant but never as abundant as in LDZ-A. A peak of Aulacoseira granulata and Aulacoseira lirata occurs in the upper third of this subzone; benthic taxa attain up to $20 \%$ abundance. This subzone is also found in core NE97-7PC (Figure 3 ) and has been stratigraphically correlated in core NE97-5PC (Figure 5).

3.4.2.3. Subzone B3 The interval from the top of subzone B2 to $1.75 \mathrm{~m}$ in NE98-1PC ( 11,500-7,000 cal yr BP). Characteristic of this subzone are the high abundances of benthic diatoms in the upper and lower thirds of this interval, and low abundances of C. stelligera-complex. A peak of the benthic taxon Pseudostaurosira zeilleri occurs near the base of the zone. Higher abundances (up to 15\%) of sponge spicules are encountered toward the bottom of this interval. An abrupt decrease of $C$. andina and increasing abundances of $C$. meneghiniana mark the transition to LDZ-C. Subzone B3 is also encountered in core NE97-7PC (Figure 3). 
Table 4.

Designated biostratigraphic boundaries and ${ }^{14} \mathrm{C}$ ages (cal yr BP) used in core NE97-5PC

\begin{tabular}{lrr}
\hline Age type & $\begin{array}{r}\text { Core depth } \\
(\mathrm{cm})\end{array}$ & $\begin{array}{r}\text { Age } \\
(\text { cal yr BP) }\end{array}$ \\
\hline TB2 & 0 & 11,500 \\
$\mathrm{BB} 2$ & 200 & 17,000 \\
$\mathrm{~TB} 1$ & 250 & 17,000 \\
$\mathrm{BB} 1$ & 450 & 20,500 \\
$\mathrm{TA1}$ & 500 & 25,000 \\
${ }^{14} \mathrm{C}$ & 686 & 25,792 \\
${ }^{14} \mathrm{C}$ & 904 & 28,702 \\
${ }^{14} \mathrm{C}$ & 1,074 & 29,694 \\
\hline
\end{tabular}

First character in age type column denotes $\mathrm{T}$ (Top) and B (bottom).

\subsubsection{LSZ-C $(\sim 7,000-0$ cal yr BP $)$}

LDZ-C is present in $1 \mathrm{PC}-4 \mathrm{Bx}$ from 1.75 to $0 \mathrm{~m}$ and in the upper $3.75 \mathrm{~m}$ of core NE97-7PC. This zone is dominated by C. meneghiniana. Based on the co-occurrences of accompanying species, we divided LDZ-C into six subzones (Figure 3 and Figure 4).

\subsubsection{Subzone C1 The stratigraphic interval from} the top of subzone B3 to $1.40 \mathrm{~m}$ in NE-1PC $(\sim 7,000$ 6,200 cal yr BP). This subzone is characterized by the low abundances of $C$. andina. It also contains moderate abundances of the $C$. stelligera-complex; high abundances of benthic diatoms occur in the bottom of this interval. Subzone C1 is found in core NE977PC in the interval from 3.75 to $3.0 \mathrm{~m}$, suggesting an age range from 8,200 to 6,500 cal yr BP.

3.4.3.2. Subzone C2 The interval from the top of subzone C1 to $1.25 \mathrm{~m}$ in NE98-1PC ( 6,200-5,500 cal yr BP). Subzone C2 contains high abundances of benthic taxa (up to 90\%); the C. stelligera-complex is rare. In core NE97-7PC (Figure 3), P. zeilleri and $T$. tabulata occur in high abundances. C2 is represented in this latter core in the interval from 3.0 to $2.4 \mathrm{~m}$, indicating an age range from 6,500 to 6,000 cal yr BP.

3.4.3.3. Subzone C3 The stratigraphic interval from the top of subzone C2 to $1.05 \mathrm{~m}$ in core NE98-1PC $(\sim 5,500-4,500 \mathrm{cal}$ yr BP). This interval is character- ized by increased abundance of Chaetoceros muelleri and by the high abundances of benthic taxa (up to $60 \%$ ) in the upper part of this subzone. This subzone is present in core NE97-7PC from 2.4 to $2.0 \mathrm{~m}$ ( 6,000-5,400 cal yr BP) where P. zeilleri and other benthic taxa attain common abundances (Figure 3).

3.4.3.4. Subzone C4 The stratigraphic interval from the top of subzone C3 to $0.7 \mathrm{~m}$ in core $1 \mathrm{PC}-4 \mathrm{Bx}$ ( 4,500-3,000 cal yr BP). This subzone is characterized by high abundances of C. muelleri (up to 60\%) and low abundances (below 20\%) of benthic taxa. It also contains higher abundances of chrysophyte statocysts. In core NE97-7PC (Figure 3), C4 is present in the interval from 2.0 to $1.1 \mathrm{~m}$, indicating an age range from about 5,400 to 3,700 cal yr BP.

3.4.3.5. Subzone C5 The interval from the top of subzone C4 to $0.35 \mathrm{~m}$ in core NE98-4Bx $(\sim 3,000-$ $1,500 \mathrm{cal}$ yr BP). This subzone is characterized by the complete dominance of $C$. meneghiniana. Benthic taxa are below $20 \%$, and sponge spicules attain higher occurrences. Saline and freshwater planktonic diatoms are rare. Subzone $\mathrm{C} 5$ is present in core NE97-7PC (Figure 3) in the interval from 1.1 to 0.2 $\mathrm{m}(\sim 3,700-2,200 \mathrm{cal}$ yr BP).

3.4.3.6. Subzone C6 The stratigraphic interval from the top of subzone C5 to $0.0 \mathrm{~m}$ in core NE98-4Bx $(\sim 1,500-0$ cal yr BP). Main features of this subzone are the reappearance of $C$. andina and $C$. stelligera-complex and the decrease in the abundance of C. meneghiniana. Benthic diatoms are below 20\% abundances. This characteristic assemblage is found in the top $0.2 \mathrm{~m}(\sim 2,000-0$ cal yr BP) in core NE977PC (Figure 3).

\subsection{Modern diatom samples}

Modern phytoplankton analyses from vertical plankton tows and POM filter samples $(n=51)$ during May and June of 1996 to 1998 (Table 2) indicate the dominance of four pelagic species during the austral winter (Figure 6): Fragilaria crotonensis (up to 95\%), Cyclostephanos tholiformis (variable, up to 95\%), Cyclotella andina (up to 70\%), and Aulacoseira granulata (up to 55\%). Accompanying spe- 


\section{LAKE TITICACA, NE97-5PC}

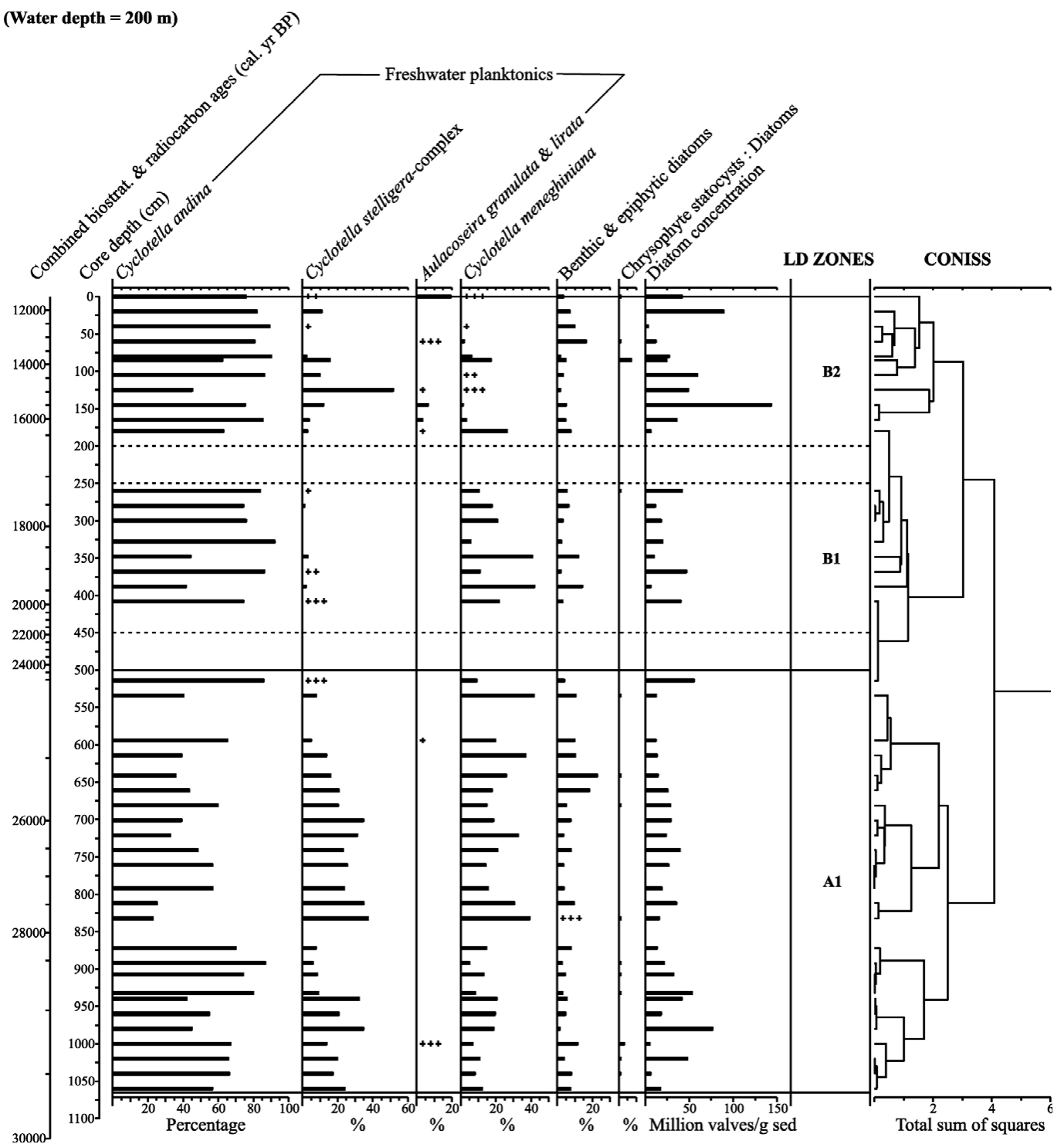

Figure 5. Diatom stratigraphy of core NE97-5PC. Diatom species are represented as percentages. Chrysophyte cysts are plotted as a percentage of total diatom count. Plus signs indicate occurrence of diatom valves, less than $1 \%$. See text for LDZ. The figure is linearly scaled based on depth; the equivalent secondary axis is based on calendar ages. Gaps in the stratigraphy are zones barren of diatom valves or where diatom concentrations were too low to generate an accurate diatom count.

cies are Synedra nana and Entomoneis paludosa var. subsalina. The planktonic species occurrences are directly proportional to the plankton net aperture (Figure 6). Filters and net with the smallest aperture (5 $\mu \mathrm{m})$ retain the solitary free-floating $C$. tholiformis, whereas the chain-forming species $F$. crotonensis and A. granulata are dominant in nets of $10 \mu \mathrm{m}$ and
$20 \mu \mathrm{m}$, respectively. Cyclotella meneghiniana and Cyclotella stelligera-complex are always rare or in abundances of less than $10 \%$. The presence of benthic species, including Cocconeis placentula and Epithemia sorex, indicate some degree of mixing of littoral taxa into the water column. No other planktonic or centric taxa are represented in the plankton tows, 


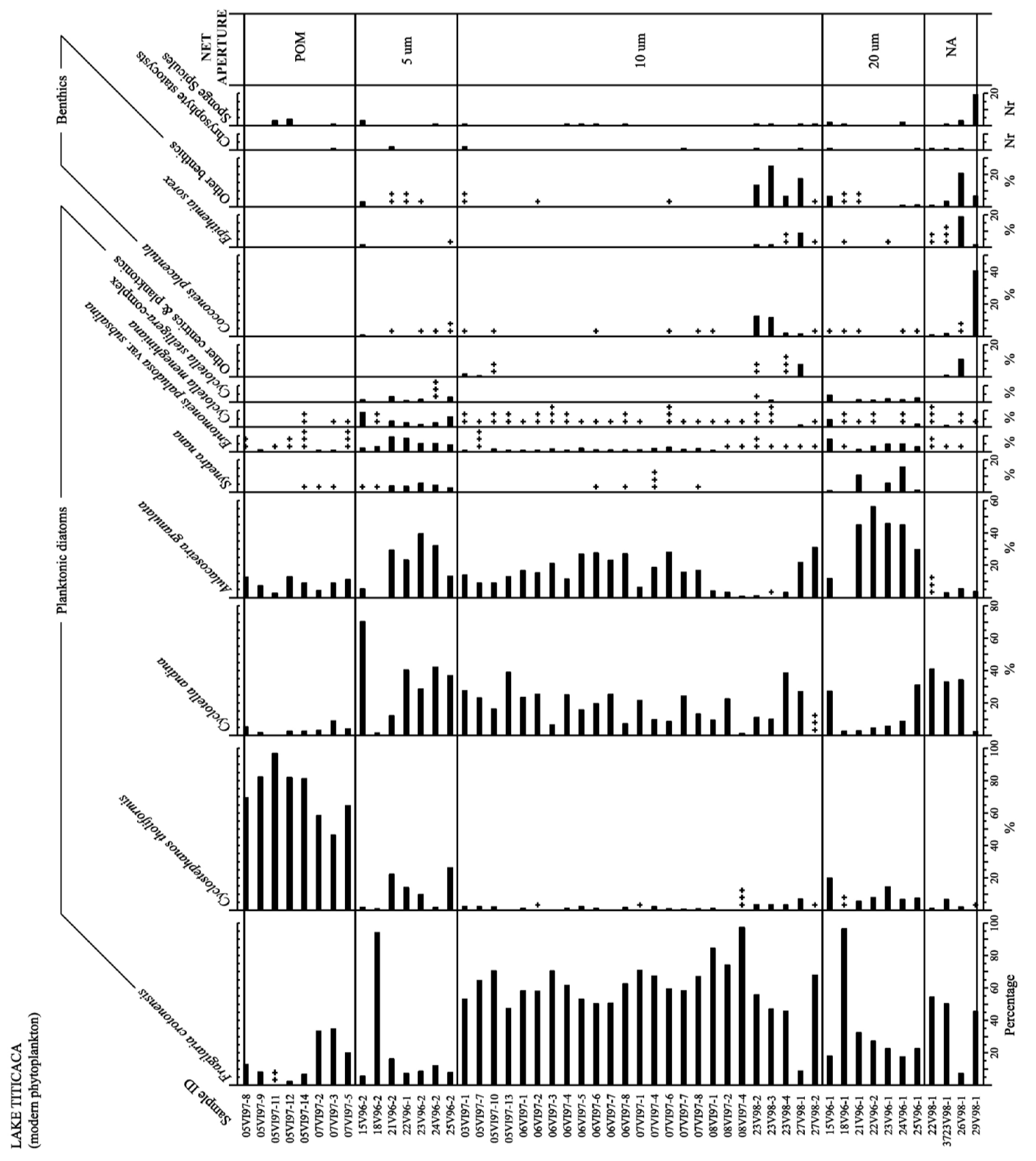




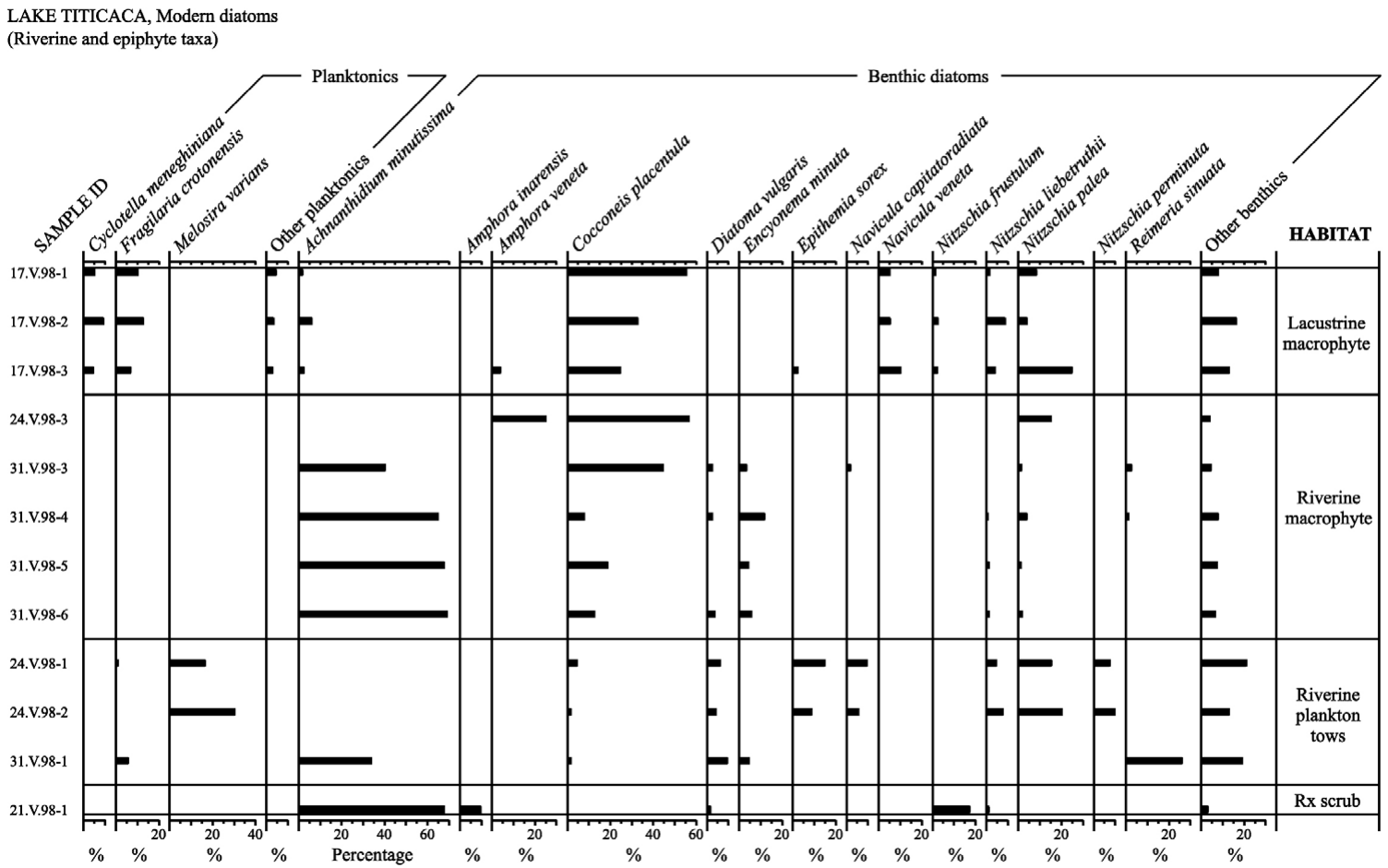

Figure 7. Species composition of modern diatom habitats around Lake Titicaca.

except Melosira varians (samples 26.V.98-1 and 27.V.98-1). This taxon indicates riverine input (see below).

Epiphytic diatoms from littoral lacustrine macrophytes (Figure 7) are dominated by C. placentula (up to $54 \%$ ) and Nitzschia palea (up to $24 \%$ ). Subdominant species are Achnanthidium minutissima, Navicula veneta, and Nitzschia liebetruthii. The planktonic species $C$. meneghiniana and F. crotonensis are minor taxa in littoral habitats. Dominant epiphytic diatoms from macrophytes in tributary rivers (Figure 7) are A. minutissima (up to 68\%) and C. placentula (up to $18 \%$ ). Amphora veneta is only well represented (24\%) in one sample (24.V.98-3). Subdominant species are Encyonema minuta and N. palea. Riverine diatoms from plankton tows (Figure 7) are dominated by the substrate-attached species Melosira varians (up to 29\%), N. palea (up to $19 \%$ ), and $E$. sorex (up to 15\%). A. minutissima and Reimeria sinuata are moderately abundant in one sample (31.V.981). Subdominant diatoms are C. placentula, Diatoma vulgaris, Navicula capitatoradiata, Nitzschia liebetruthii, and N. perminuta. Results from a scrubbedrock sample from Fuente del Inca spring on Isla del Sol (Figure 7) reveal the dominance of the species A. minutissima (67\%), whereas subdominant species are Amphora inarensis and N. frustulum.

Modern diatom assemblages in surface-sediment samples from several transects in the Chucuito subbasin (Figure 1, Table 1) are representative of the diatom-depth profile in the sub-basin. Identified planktonic diatoms are C. andina, C. stelligera-complex, F. crotonensis, C. tholiformis, A. granulata, A. lirata, E. paludosa var. subsalina, and C. meneghiniana, whereas the benthic and epiphytic diatoms include a large number of littoral and near-shore taxa, including several species of the genera Epithemia, Cocconeis, and Achnanthes. Cyclotella andina dominates the assemblages at depths greater than $35 \mathrm{~m}$. Deepwater sediments also contain significant abundances of C. stelligera-complex (1-25\%), C. meneghiniana (1-28\%), and some contribution from F. crotonen- 


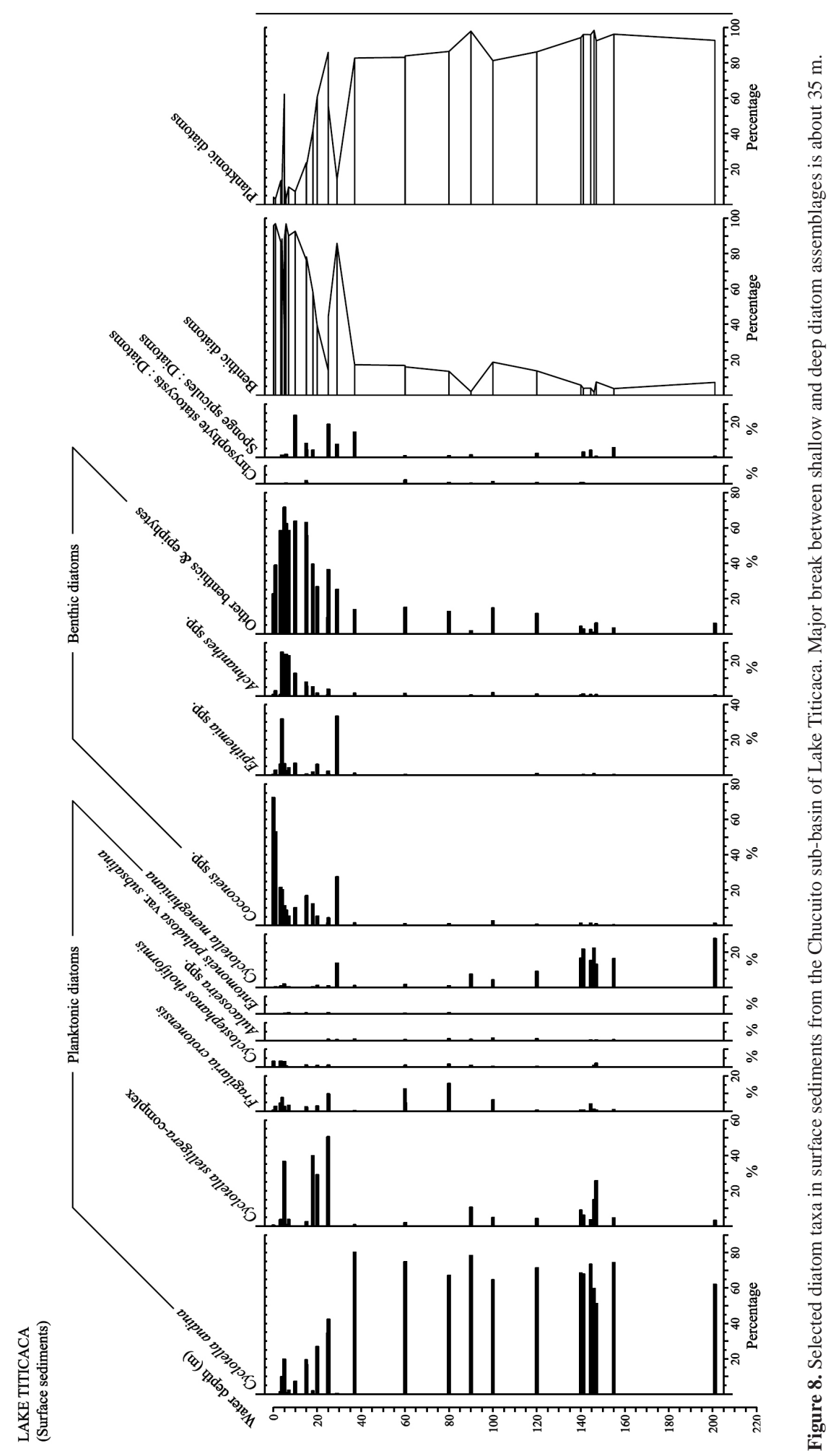


sis (1-15\%). Benthic and epiphytic diatoms dominate sediments from water depths less than $35 \mathrm{~m}$, and sponge spicules increase in abundance. The planktonic C. stelligera-complex is also common in some littoral areas (Figure 8). Rare occurrences of the species P. zeilleri and T. tabulata are found in modern riverine and lacustrine environments, as well as in surface sediments.

The depth profile of diatom distribution indicates a clear break between modern pelagic (deep-water) and neritic (shallow-water, littoral) assemblages at water depths below $35 \mathrm{~m}$. This trend is well represented by the percentage of benthic diatoms versus water depth (Figure 8). Almost all the surface-sediment samples at depths greater than $35 \mathrm{~m}$ contain less than $20 \%$ benthic diatoms. The sample with high peak of benthic diatoms at a depth of 29 m (sample NE98-11BxB, 0-1 cm) is from the Puno Bay area, a shallow bay that is heavily enriched with nutrients.

The abundance of diatoms and other components of the primary producers in modern times is indirectly indicated by 16 Secchi depth readings (Table 2) made during three austral winters (May 1996, June 1997, May 1998), the season in which phytoplankton biomass is most abundant (Richerson et al., 1975). These readings range from 5.5 to $15.5 \mathrm{~m}$ (mean $=8.4$ $\pm 2.15 \mathrm{~m}$, mode $=8.5 \mathrm{~m}$ ) implying that the photic zone averages about $20 \mathrm{~m}$, with a maximum depth of about $35 \mathrm{~m}$. Our readings are in agreement with previous Secchi measurements in the Chucuito sub-basin (Richerson et al., 1975 and Vincent et al., 1986). Thus, it is unlikely that benthic taxa are able to live below $40 \mathrm{~m}$. Therefore, benthic diatoms found in samples of deeper depths probably occur there because of sediment mixing from shallow to deep-waters. We consider an amount of $20 \%$ or lower of benthic diatoms to be a typical "background" level in deep-water sediments.

\section{Discussion}

Analyses of modern diatoms in surface-sediment samples form the primary basis to interpret the core records supplemented by other autoecological stud- ies of diatom distribution. The modern diatom record shows three important features: (1) abundant planktonic freshwater taxa in deep water, dominated by Cyclotella andina with lower percentages of Cyclotella meneghiniana, Cyclotella stelligera-complex, and Fragilaria crotonensis; (2) high abundances of shallow-water benthic taxa confined to depths less than $30 \mathrm{~m}$; and (3) background levels of benthic flora, equal to or less than $20 \%$ of the total diatom count, in depths greater than $30 \mathrm{~m}$.

We focus our discussion on the results from the complementary cores NE98-1PC and NE98-4BxB, because they represent the most complete record of the deep basin of Lake Titicaca. The cores register the predominance of two freshwater and pelagic taxa: C. andina and the C. stelligera-complex, and in some zones $C$. meneghiniana. On the basis of the surface-sediment distribution, C. andina is dominant at water depths greater than $35 \mathrm{~m}$. Cyclotella stelligera is now encountered in depths from $140 \mathrm{~m}$ to shallower waters, although it is more common at depths $\leq 25 \mathrm{~m}$. Although increased abundances of $C$. stelligera-complex might represent times of reduced water depths, it clearly indicates freshwater conditions based on studies of its distribution in other localities. Therefore, dominance of these two taxa is interpreted as signifying high lake levels with overflowing conditions (as in the present) and without elevated concentration of salts. In contrast, C. meneghiniana occurs in saline and freshwater lakes and spans a wide range of depths.

Cyclosthephanos tholiformis and F. crotonensis are two weakly silicified pelagic taxa common in modern phytoplankton samples but less well represented in surface-sediment and core samples. One possible cause of their low abundance in modern sediments is that surface sediments are influenced by the high $\mathrm{pH}$ of Lake Titicaca waters, which induces selective dissolution of these lightly silicified diatoms. Aulacoseira species are also not well represented in the surface sediments, although they were moderately well represented in the modern water column of May-June (1996-1998). We can rule out dissolution effects in this case, because representatives of this genus contain heavily silicified frustules. This suggests that the taxa regis- 
tered in 1996-1998 may not be representative of the long-term average. Nonetheless, when found in core samples, Aulacoseira signifies freshwater and moderately high lake levels based on autoecological studies from other regions.

Although the planktonic species Chaetoceros muelleri has no modern analog in the entire Altiplano basin, our association of C. muelleri with highly saline waters and lower water levels is secure, based on its co-occurrence with high abundances of benthic taxa, as well as the consistent occurrence of this species in lakes with elevated salinity data in other regions (Gasse, 1986; Fritz et al., 1993; Cumming et al., 1995; and Snoeijs and Kasperoviciene, 1996). Elevated percentages (up to $85 \%$ ) of Chaetoceros sp. were reported in surface sediments of Lake Poopó (Servant-Vildary, 1978b and Sylvestre et al., 2001) with a modern salinity range from 14.66 to $39.61 \mathrm{~g} \mathrm{l}^{-1}$.

Our diatom-based paleoclimatic interpretation is based on the changes in relative abundance of planktonic freshwater, planktonic salinity-indifferent (C. meneghiniana), planktonic saline (C. muelleri), and benthic assemblages (Figure 9) in the four cores. The low percentage (background level is $\leq 20 \%$ ) of benthic diatoms (Figure 9B) from 31,500 to 16,000 cal yr BP, coupled with high percentages $(>70 \%)$ of freshwater pelagic diatoms (Figure 9A), indicates overflow conditions. The relative abundance of C. meneghiniana (Figure 9D) increased up to $50 \%$ at the expense of $C$. andina in the period from 26,000 to 20,000 cal yr BP, which may indicate minor lake regression or increasingly eutrophic waters. Modern autoecological and physiological experiments on $C$. meneghiniana indicate a wide salinity tolerance from freshwater to oligosaline ( $<10 \mathrm{~g} \mathrm{l}^{-1}$ TDS) waters and a preference for eutrophic environments (Håkansson and Chepurnov, 1999). We did not encounter C. meneghiniana with truly pelagic saline taxa during this period $(26,000-$ 20,000 cal yr BP), nor with high abundances of benthic diatoms to suggest shallow waters. Instead, we found $C$. meneghiniana associated with the freshwater planktonic species Fragilaria crotonensis. Although increases of this species are associated with higher nutrient levels in other regions, this hypothesis is not supported by modern phytoplankton species composition in the eutrophic Puno Bay area (Carney et al., 1987), in which specimens of $C$. meneghiniana are rare. Rare occurrences of this taxon are reported from plankton samples of the mesotrophic Huiñaymarca sub-basin (ServantVildary, 1992), as well as in the shallow saline Lake Poopó (Sylvestre et al., 2001). Thus, during the period from 26,000 to $20,000 \mathrm{cal}$ yr $\mathrm{BP}$, higher $C$. meneghiniana abundance is interpreted as representative of freshwater and lake level at the outlet, although why the planktonic diatom composition shifted during this part of the last glacial stage remains unclear. A possible scenario is that short-term droughts induced increased water residence time, which affected the relative dominance of planktonic diatoms and/or that temperature and wind changes affected the duration of stratification periods and the mixing of nutrients from the hypolimnion. In any case, the data suggest that the glacial environment in Lake Titicaca was somehow different than in the late-glacial stages when the abundances of $C$. meneghiniana were reduced.

Overall, wet conditions remained until 11,500 cal yr BP, as indicated by the steady high abundance of freshwater pelagic diatoms. The high abundance of Aulacoseira species from about 12,500 to $12,000 \mathrm{cal}$ yr BP suggests fresh waters, combined with enhanced or extended periods of deepwater mixing. The transition between late-glacial and Holocene times was characterized by a short interval of a large-amplitude increase in the benthic diatom abundance, which suggests a brief water-level decline between $~ 11,000$ and $10,000 \mathrm{cal}$ yr BP. Wet conditions producing high, possibly overflowing, lake levels occurred between 10,000 and 8,000 cal yr BP, when an intense lakelevel decline began, as freshwater planktonic diatoms abruptly disappeared and were replaced by benthic taxa and C. meneghiniana. In NE98-1PC (Figure $9 \mathrm{~A}$ ), a spike in the abundance of freshwater taxa suggests a wetter period between 7,500 and 6,500 cal yr BP. Salt build-up in the lake is indicated by the presence of the saline planktonic species Chaetoceros muelleri (Figure 9C) in the period from 6,000 to $3,500 \mathrm{cal}$ yr BP, with highest abundances at about $4,500 \mathrm{cal}$ yr BP. The long period of low lake level 


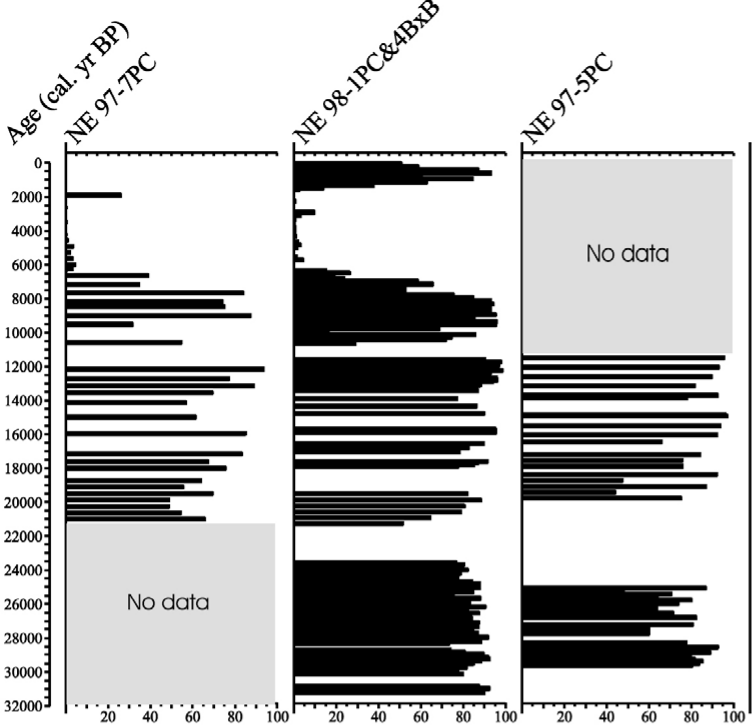

A

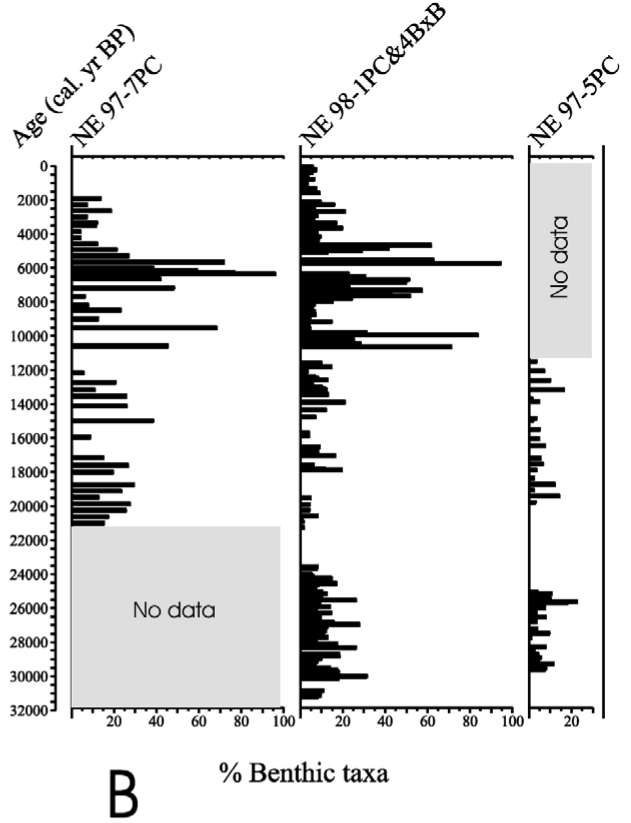

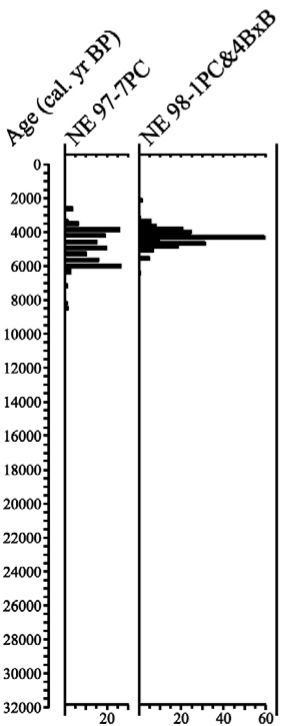

$\%$ Saline Planktonic taxa

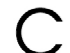

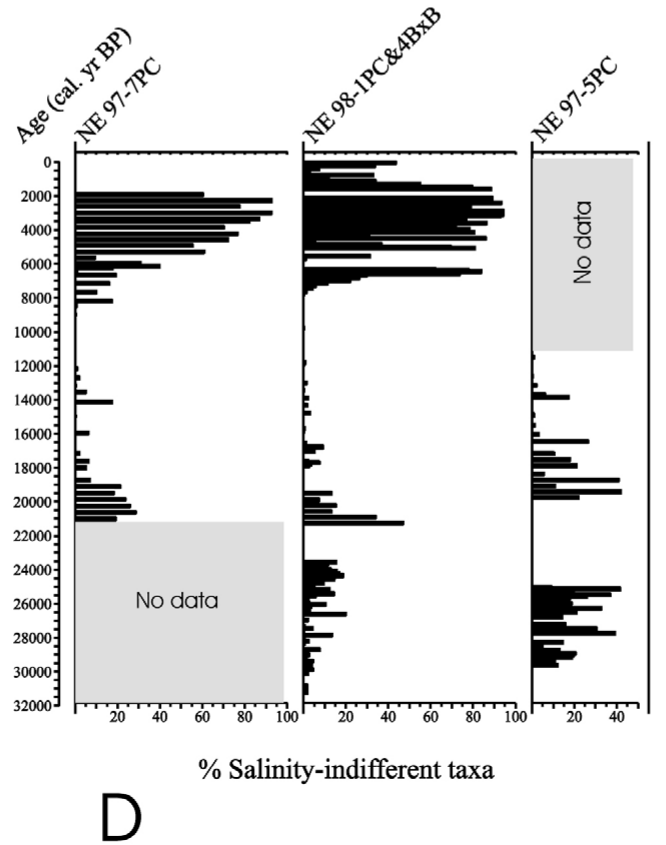

Figure 9. Changes in diatom dominance for the past 31,500 cal yr BP in Lake Titicaca. Diatom groups represent the four different ecological groups that prevailed in the basin. Gaps in the stratigraphy are zones barren of diatom valves or where diatom concentrations were too low to generate an accurate diatom count. Core NE97-7PC does not extend to times prior to 21,000 cal yr BP, whereas the core NE97-5PC record terminates at about 12,000 cal yr BP (shaded gray areas). 
ended after 4,000 cal yr BP, when benthic diatoms diminished in abundance to background levels. High percentages of C. meneghiniana, low abundances of benthic taxa, and the progressive increase of freshwater planktonic diatoms record the lake transgression. Conditions similar to the modern lake were attained by 1,500 cal yr BP, when C. andina became dominant, C. muelleri disappeared, and benthic taxa remain at background levels. The piston cores NE977PC and NE98-1PC illustrate the same general trends, although because the core NE97-7PC was recovered from a shallower water depth (85 m), it contains a correspondingly higher proportion of benthic taxa (Figure 9B).

The Lake Titicaca diatom record indicates longterm climate changes in the Altiplano region. Wet conditions prevailed in the LGM and during much of the late glacial. This phase overlaps with the Tauca high lakestand (ca. 26,000-15,000 cal yr BP sensu Baker et al., 2001b), which has been documented from paleoshorelines, outcrops, and core sediments in the central Bolivian Altiplano (Servant and Fontes, 1978; Lavenu, 1992; Servant-Vildary and Mello e Sousa, 1993; Servant et al., 1995; Sylvestre et al., 1996; Sylvestre et al., 1998; Sylvestre et al., 1999; Baker et al., 2001b; and Sylvestre, 2002). Earlier paleoclimate reconstructions in the Huiñaymarca sub-basin of Lake Titicaca interpreted the low abundance of planktonic chlorophytes (Botryococcus, Pediastrum) as representing low lake levels during the LGM (Wirrmann et al., 1992; Mourguiart et al., 1997; Mourguiart et al., 1998; and Mourguiart, 1999). However, we disagree with this interpretation because of the wide ecological tolerances of these taxa, and because our data show a dominance of freshwater planktonic diatoms indicative of fresh overflowing conditions. Glacial-age ice from Nevado Sajama, about 200 km southwest of Lake Titicaca, has low concentrations of dust, possibly because of moist conditions in the late glacial stage during paleolake Tauca (Thompson et al., 1998).

Wet and dry conditions characterized the latter part of late-glacial times. Conditions were generally wet up to $11,000 \mathrm{cal}$ yr BP. The latter part of this late-glacial sequence is correlated with high lake lev- els at Laguna Lejia at the Chilean Altiplano (Grosjean, 1994), a wet phase in core sediments at Salar de Uyuni (Baker et al., 2001b), and overlaps with the European Younger Dryas cold event (Baker et al., 2001a). The wet phase was followed by a millennial-scale drought (11,000-10,000 cal yr BP). Our data do not show evidence of the extended dry Ticaña event between ca. 14,000 and 10,500 cal yr BP as described from the Salar de Coipasa, central Altiplano (Sylvestre et al., 1999).

The onset of the Holocene is marked by a wet phase, which lasted until 8,500 cal yr BP, which may be partially correlated with the wet Coipasa event (ca. 10,500-9,500 cal yr BP) in the central Altiplano (Sylvestre et al., 1999). This is followed by a long arid phase from 8,000 to 4,000 cal yr BP, which is interrupted by a brief wet period from 7,500 to 6,500 cal yr BP. In this early- to mid-Holocene arid period, we found diatom evidence of shallow and saline waters, which corroborates reconstructions for the mid-Holocene from surface cores in the Chucuito sub-basin of Lake Titicaca (Cross et al., 2000). Our other proxy records based on stable oxygen and carbon isotopes, $\mathrm{CaCO}_{3}$ and $\mathrm{C} / \mathrm{N}$ ratios also indicate extreme arid conditions during the mid-Holocene (Cross et al., 2000; Baker et al., 2001a; and Rowe et al., 2002). Seismic data show that Lake Titicaca fell to at least $85 \mathrm{~m}$ below modern lake level during the phase of maximum aridity (Seltzer et al., 1998). An extreme period of mid-Holocene aridity has also been recorded in Laguna Miscanti, Laguna Seca, and Laguna del Negro Francisco in Chile and Argentina (Valero-Garcés et al., 1996; Schwalb et al., 1999; and Grosjean et al., 2001).

Recently this scenario of widespread mid-Holocene hyper-aridity throughout the tropical Andes has been challenged by evidence from fossil rodent middens and wetland deposits in the Atacama desert region (Betancourt et al., 2000; Holmgren et al., 2001; Latorre et al., 2002; and Rech et al., 2002) and from lake deposits in southwestern Peru (Placzek et al., 2001). Currently data are insufficient to clearly explain the dissimilarity between the northern Altiplano records and those from the Atacama region. However, decadal-scale wet episodes may explain the periods of elevated pollen grains in fossil rodent 
middens during parts of the mid-Holocene (Grosjean, 2001).

Wet climatic conditions reoccurred in Lake Titicaca after 4,000 cal yr BP as precipitation filled the Titicaca basin and overflow conditions were re-established. Our relative paleohydrological estimates agree with lake-level reconstructions based upon lithology and ostracod and pollen assemblages in the Huiñaymarca sub-basin (Wirrmann et al., 1992; Abbott et al., 1997; Mourguiart et al., 1992; Mourguiart et al., 1997; Mourguiart et al., 1998; and Mourguiart, 1999), as well as the timing of lacustrine deposits in the Rio Desaguadero valley (Baucom and Rigsby, 1999).

Because of changes in solar radiation driven by orbital variations, models predict increased precipitation and monsoonal activity in the northern tropics during the early to mid-Holocene (COHMAP, 1988), predictions that are compatible with Caribbean and mesoamerican data (Hodell et al., 1991; Bradbury, 1997; and Markgraf, 1993). The opposite pattern is predicted for the southern tropics of South America and is consistent with evidence from the Altiplano lakes, which indicate extreme aridity (Cross et al., 2000; Baker et al., 2001a; Grosjean et al., 2001; and Rowe et al., 2002). During the LGM, when summer insolation was high in the Southern Hemisphere tropics, Andean precipitation increased, probably because of increased advection of moisture from the Amazon basin, induced by the southerly displacement of the ITCZ. Thus, our data are consistent with large-scale control of southern tropical moisture conditions by austral summer-insolation influence on the South American Summer Monsoon.

In sumary, two broad contrasting climatic patterns governed the Altiplano over the past 30,000 years: (1) a wet phase during the LGM until late-glacial times, which implies wet conditions in Amazonia, and (2) an extensive dry phase in the mid-Holocene. Moreover, we notice that the diatom record in Lake Titicaca is highly sensitive to climatic changes and also registers millennial-scale climate variability in lateglacial to Holocene times, coincident with times of climatic changes in the North Atlantic region (Baker et al., 2001a).

\section{Acknowledgements}

We would like to acknowledge the assistance of the Autoridad Autonoma del Lago Titicaca and its directors, Ing. Julio Sanjines and Ing. Mario Revollo throughout the duration of our work in Lake Titicaca. James Broda, Harold Rowe, Mathew Grove, Nicolas Catari, and Gonzalo Mollaricon assisted with fieldwork. Mark Busch provided several ${ }^{14} \mathrm{C}$ dates. Simone Servant-Vildary shared surface-sediment data from Yunguyo Bay. Brian Cummings and Platt Bradbury gave valuable comments and editorial suggestions to improve this manuscript. Funds were provided by the National Science Foundation to S.C.F., G.O.S., P.A.B., and R.B.D. This contribution is in partial fulfillment of requirements of P.M.T. for a doctoral degree at the University of Nebraska-Lincoln.

\section{References}

Abbott, M.B., Binford, M.W., Brenner, M. and Kelts, K.R., 1997. A $3500{ }^{14} \mathrm{C}$ yr high-resolution record of waterlevel changes in Lake Titicaca, Bolivia/Peru. Quat. Res. 47, pp. 169-180.

Baker, P.A., Seltzer, G.O., Fritz, S.C., Dunbar, R.B., Grove, M.J., Tapia, P.M., Cross, S.L., Rowe, H.D. and Broda, J.P., 2001. The history of South American tropical precipitation for the past 25,000 years. Science 291, pp. 640-643.

Baker, P.A., Rigsby, C.A., Seltzer, G.O., Fritz, S.C., Lowenstein, T.K., Bacher, N.P. and Veliz, C., 2001. Tropical climate changes at millennial and orbital timescales on the Bolivian Altiplano. Nature 409, pp. 698-700.

Bard, E., 1998. Geochemical and geophysical implications of the radiocarbon calibration. Geochim. Cosmochim. Acta 62, pp. 2025-2038.

Battarbee, R.W. and Kneen, M.J., 1982. The use of electronically counted microspheres in absolute diatom analysis. Limnol. Oceanogr. 27, pp. 184-188.

Battarbee, R.W., 1986. Diatom analysis. In: Berglund, B.E. (Ed.), Handbook of Holocene Palaeoecology and Palaeohydrology. Wiley, Chichester, pp. 527-570.

Baucom, P.C. and Rigsby, C.A., 1999. Climate and lakelevel history of the northern Altiplano, Bolivia, as recorded in Holocene sediments of the Rio Desaguadero. J. Sediment. Res. 69, pp. 597-611.

Betancourt, J.L., Latorre, C., Rech, J.A., Quade, J. and Rylander, K.A., 2000. A 22,000-year record of monsoonal precipitation from northern Chile's Atacama desert. Science 289, pp. 1542-1546.

Bradbury, J.P., 1997. Sources of glacial moisture in Mesoamerica. Quat. Int. 43/44, pp. 97-110. 
Bush, M.B., Colinvaux, P.A., Wiemann, M.C., Piperno, D.R. and Liu, K.-b., 1990. Late Pleistocene temperature depression and vegetation change in Ecuadorian Amazonia. Quat. Res. 34, pp. 330-345.

Carney, H.J., Richerson, P.J. and Eloranta, P., 1987. Lake Titicaca (Peru/Bolivia) phytoplankton: Species composition and structural comparison with other tropical lakes. Arch. Hydrobiol. 110, pp. 365-385.

Clapperton, C.M., 1993. Nature of environmental changes in South America at the Last Glacial Maximum. $\mathrm{Pa}$ laeogeogr. Palaeoclimatol. Palaeoecol. 101, pp. 189-208.

COHMAP Members, 1988. Climatic changes of the last 18,000 years: observations and model simulations. Science 241, 1043-1052.

Colinvaux, P.A., De Oliveira, P.E. and Bush, M.B., 2000. Amazonian and neotropical plant communities on glacial time-scales: The failure of the aridity and refuge hypotheses. Quat. Sci. Rev. 19, pp. 141-169.

Cross, S.L., Baker, P.A., Seltzer, G.O., Fritz, S.C. and Dunbar, R.B., 2000. A new estimate of the Holocene lowstand level of Lake Titicaca, central Andes, and implications for tropical palaeohydrology. Holocene 10, pp. 21-32.

Cumming, B.F., Wilson, S.E., Hall, R.I. and Smol, J.P., 1995. Diatoms from British Columbia (Canada) lakes and their distribution to salinity, nutrients, and other limnological variables. Bibl. Diatomol. 31, pp. 1-207.

Frenguelli, G., 1929. Diatomee fossili delle conche saline del deserto Cileno-Boliviano. Boll. Soc. Geol. Ital. 47, pp. 185-236.

Frenguelli, J., 1934. Diatomeas del tripoli de San Pedro de Atacama. Rev. Chil. Hist. Nat. 38, pp. 159-163.

Frenguelli, J., 1936. Diatomeas de la caliza de la cuenca de Calama. Rev. Mus. La Plata. Nueva Ser. Paleontol. 1, pp. 3-34.

Frenguelli, J., 1939. Diatomeas del Lago Titicaca. Notas Mus. La Plata Botan. 4, pp. 175-196.

Fritz, S.C., Juggins, S. and Battarbee, R.W., 1993. Diatom assamblages and ionic characteriation of lakes of the Northern Great Plains, North America: A tool for reconstructing past salinity and climate fluctuations. Can. J. Fish. Aquat. Sci. 50, pp. 1844-1856.

Garreaud, R.D., 1999. Multiscale analysis of the summertime precipitation over the Central Andes. Mon. Weather Rev. 127, pp. 901-921.

Gasse, F., 1986. East African diatoms. Taxonomy, ecological diatribution. Bibl. Diatomol. 11, pp. 1-201.

Germain, H., 1981. Flore des diatomées. Diatomophycées. Eux douces et soumâtres du Massif Armoricain et des contrées voisines d'Europe occidentale. Soc. Nouvelle des Éditions Boubée, 444 pp.

Grimm, E., 1987. CONISS: A Fortran 77 program for stratigraphically constrained cluster analysis by the method of incremental sum of squares. Comput. Geosci. 13, pp. 13-35.

Grosjean, M., 1994. Paleohydrology of the Laguna Lejía (north Chilean Altiplano) and climatic implications for late-glacial times. Palaeogeogr. Palaeoclimatol. Palaeoecol. 109, pp. 89-100.

Grosjean, M., 2001. Mid-Holocene climate in the southcentral Andes: humid or dry?. Science 292, p. 2391.

Grosjean, M., van Leeuwen, J.F.N., van der Knaap, W.O., Geyh, M.A., Ammann, B., Tanner, W., Messerli, B., Nuñez, L.A., Valero-Garcés, B.L. and Veit, H., 2001. A 22,000 ${ }^{14} \mathrm{C}$ year BP sediment and pollen record of climate change from Laguna Miscanti (23ㅇ), northern Chile. Glob. Plant. Change 28, pp. 35-51.

Haberle, S. and Maslin, M., 1999. Late Quaternary vegetation and climate change in the Amazon basin based on a 50,000 year pollen record from the Amazon fan, ODP Site 932. Quat. Res. 51, pp. 27-38.

Håkansson, H. and Chepurnov, V., 1999. A study of variation in valve morphology of the diatom Cyclotella meneghiniana in monoclonal cultures: effect of auxospore formation and different salinity conditions. Diatom Res. 14, pp. 251-272.

Hodell, D.A., Curtis, J.H., Jones, G.A., Higuera-Gundy, A., Brenner, M., Binford, M.W. and Dorsey, K.T., 1991. Reconstruction of Caribbean climate change over the past 10,500 years. Nature 352, pp. 790-793.

Holmgren, C.A., Betancourt, J.L., Rylander, K.A., Roque, J., Tovar, O., Zeballos, H., Linares, E. and Quade, J., 2001. Holocene vegetation history from fossil rodent middens near Arequipa, Peru. Quat. Res. 56, pp. 242-251.

Hooghiemstra, H. and van der Hammen, T., 1998. Neogene and Quaternary development of the neotropical rain forest: the forest refugia hypothesis, and a literature overview. Earth Sci. Rev. 44, pp. 147-183.

Hostetler, S.W. and Mix, A.C., 1999. Reassessment of iceage cooling of the tropical ocean and atmosphere. $\mathrm{Na}$ ture 399, pp. 673-676.

Hustedt, F., 1927. Fossile Bacillariaceen aus dem LoaBecken in der Atacama-Wüste, Chile. Arch. Hydrobiol. 18, pp. 224-251.

Hustedt, F., 1930. Bacillariophyta (Diatomeae). In: Prof. Dr. A. Pascher, Die Süsswasser-Flora Mitteleuropas, Heft 10. Gustav Fischer, Jena, 466 pp.

Hustedt, F., 1930-1966. Die Kieselalgen Deutschlands, Österreichs und der Schweiz unter Berücksichtigung der übrigen Länder Europas sowie der angrenzenden Meeresgebiete. In: Dr. L. Rabenhorsts, KryptogamenFlora von Deutschlands, Österreichs und der Schweiz. Band 7. Teil 1 (1930), 920 pp., Teil 2 (1931-1959), 845 pp., Teil 3 (1961-1966), 816 pp.

Iltis, A., Risacher, F. and Servant-Vildary, S., 1984. Contribution à l'étude hydrobiologique des lacs salés du sud de l'Atiplano Bolivien. Rev. Hydrobiol. Trop. 17, pp. 259-273.

Krammer, K., Lange-Bertalot, H., 1991-2000. Bacillariophyceae. In: Süßwasserflora von Mitteleuropa. Band 2: Teil 1 (1997), Naviculaceae, 876 pp.; Teil 2 (1997), Bacillariaceae, Epihtemiaceae, Surirellaceae, 610 pp.; Teil 3 (1991), Centrales, Fragilariaceae, Eunotiaceae, 576 pp.; Teil 4 (1991), Achnanthaceae, 437 pp.; Part 5 (2000), Key’s English and French translations, 311 pp. 
Lange-Bertalot, H., Külbs, K., Lauser, T., Nörpel-Schempp, M., Willmann, M., 1996. Dokumentation und Revision der von Georg Krasske beschriebenen DiatomeenTaxa. Iconographia Diatomologica, Vol. 3. Koeltz Scientific Books, 358 pp.

Latorre, C., Betancourt, J.L., Rylander, K.A. and Quade, J., 2002. Vegetation invasions into absolute desert: A 45,000 yr rodent midden record from the Calama-Salar de Atacama basins, northern Chile (lat $22^{\circ}-24^{\circ} \mathrm{S}$ ). GSA Bull. 114, pp. 349-366.

Lavenu, A., 1992. Formation and geological evolution. In: Dejoux, C., Iltis, A. (Eds.), Lake Titicaca. A Synthesis of Limnological Knowledge. Monogr. Biol. 68. Kluwer Academic, Dordrecht, pp. 3-15.

Lenters, J.D. and Cook, K.H., 1997. On the origin of the Bolivian High and related circulation features of the South American climate. J. Atmos. Sci. 54, pp. 656-677.

Manguin, E., 1964. Contribution a la connaissance des diatomées des Andes du Pérou. Mém. Mus. Nat. d'Hist. Nat., Sér. B, Botanique 12, pp. 41-98.

Markgraf, V., 1993. Climatic history of Central and South America since 18,000 yr B.P.: comparison of pollen records and model simulations. In: Wright Jr., H.E., Kutzbach, J.E., et al. (Eds.), Global Climates since the Last Glacial Maximum. University of Minnesota Press, pp. 357-385.

Metzeltin, D., Lange-Bertalot, H., 1998. Tropische Diatomeen in Südamerika I. Iconographia Diatomologica, Vol. 5. Koeltz Scientific Books, 695 pp.

Miskane, N., 1992. Distribution spatiale des diatomées dans les sédiments superficiels du lac Titicaca en Bolivie. Mém. de D.E.A. 'Quaternarie: Géologie, Paléntologie Humanie Préhistorie’, Paris, 61 pp.

Mourguiart, P., 1999. Commentaire à la note de Florence Sylvestre, Simone Servant-Vildary et Michel Servant. C. R. Acad. Sci. Paris Série IIa, Sciences de la terre et des planètes 329, pp. 153-155.

Mourguiart, P., Argollo, J., Corrège, T., Martin, L., Montenegro, M.E., Siffedine, A. and Wirrmann, D., 1997. Changements limnologiques et climatologiques dans le bassin du lac Titicaca (Bolivie), depuis 30,000 ans. C. R. Acad. Sci. Paris, Sciences de la terre et des planètes 325, pp. 139-146.

Mourguiart, P., Corrège, T., Wirrmann, D., Argollo, J., Martin, L., Montenegro, M.E., Pourchet, M. and Carbonel, P., 1998. Holocene palaeohydrology of Lake Titicaca estimated from an ostracod-based transfer function. Paleogeogr. Paleoclimatol. Paleoecol. 143, pp. 51-72.

Mourguiart, P., Wirrmann, D., Fournier, M. and Servant, M., 1992. Reconstruction quantitative des niveaux du petit lac Tititcaca au cours de l'Holocène. C. R. Acad. Sci. Paris Série II 315, pp. 875-880.

Patrick, R., 1961. Diatoms (Bacillariophyceae) from the alimentary track of Phoenicoparrus jamesi (Sclater). Postilla Yale Peabody Museum of Natural History 49, pp. 43-57.
Patrick, R., Reimer, C.W., 1966-1975. The diatoms of the United States. The Academy of Natural Sciences of Philadelphia Monogr. 13, Vol 1 (1966), 688 pp.; Vol 2 (1975), Part 1, 213 pp.

Placzek, C., Quade, J. and Betancourt, J.L., 2001. Holocene lake-level fluctuations of Lake Aricota, southern Peru. Quat. Res. 56, pp. 181-190.

Rech, J.A., Quade, J. and Betancourt, J.L., 2002. Late Quaternary paleohydrology of the central Atacama desert (lat $22^{\circ}-24^{\circ}$ S), Chile. GSA Bull. 114, pp. 334-348.

Reichardt, E., 1995. Die Diatomeen (Bacillariophyceae) in Ehrenbergs Material von Cayenne, Guyana Gallica (1843). In: Lange-Bertalot, H. (Ed), Iconographia Diatomologica. Annotated Diatom Micrographs, Vol. 1. Koeltz Scientific Books, Königstein, 107 pp.

Richerson, P.J., Widmer, C., Kittel, T. and Landa, A., 1975. A survey of the physical and chemical limnology of Lake Titicaca. Verh. Int. Ver. Limnol. 19, pp. 1498-1503.

Roche, M.A., Bourges, J., Cortes, J., Mattos, R., 1992. Climatology and hydrology of the Lake Titicaca basin. In: Dejoux, C., Iltis, A. (Eds.), Lake Titicaca. A Synthesis of Limnological Knowledge. Monogr. Biol. 68. Kluwer Academic, Dordrecht, pp. 63-88.

Rowe, H.D., Dunbar, R.B., Mucciarone, D.A., Seltzer, G.O., Baker, P.A. and Fritz, S., 2002. Insolation, moisture balance and climate change on the South American Altiplano since the Last Glacial Maximum. Clim. Change 52, pp. 175-199.

Rumrich, U., Lange-Bertalot, H., Rumrich, M., 2000. Diatomeen der Anden. Von Venezuela bis Patagonien/ Feuerland und zwei weitere Beiträge. Iconographia Diatomologica, Vol. 9. Koeltz Scientific Books, 673 pp.

Schmidt, A. (et seq.) 1874-1959. Atlas der DiatomaceenKunde. O.R. Reisland, Leipzig, Pl. 1-480.

Schwalb, A., Burns, S.J. and Kelts, K., 1999. Holocene environments from stable isotope stratigraphy of ostracods and authigenic carbonate in Chilean Altiplano lakes. Paleogeogr. Paleoclimatol. Paleoecol. 148, pp. 153-168.

Seltzer, G.O., 1994. Climatic interpretation of alpine snowline variations on millennial time scales. Quat. Res. 41, pp. 154-159.

Seltzer, G.O., Baker, P., Cross, S., Dunbar, R. and Fritz, S., 1998. High-resolution seismic reflection profiles from Lake Titicaca, Peru-Bolivia: Evidence for Holocene aridity in the tropical Andes. Geology 26, pp. 167-170.

Seltzer, G.O., Rodbell, D.T., Baker, P.A., Fritz, S.C., Tapia, P.M., Rowe, H.D. and Dunbar, R.B., 2002. Early warming of tropical South America at the last glacialinterglacial transition. Science 296, pp. 1685-1686.

Servant, M. and Fontes, J.C., 1978. Les lacs quaternaires des hauts plateaux des Andes boliviennes. Premières interprétations paléoclimatiques. Cah. ORSTOM, Sér. Géol. 10, pp. 79-97.

Servant, M., Fournier, M., Argollo, J., Servant-Vildary, S., Sylvestre, F., Wirrmann, D. and Ybert, J.-P., 1995. La dernière transition glaciaire/interglaciaire des Andes 
tropicales sud (Bolivie) d'après létude des variations des niveaux lacustres et des fluctuations glaciaires. $C$. R. Acad. Sci. Paris Série IIa 320, pp. 729-736.

Servant-Vildary, S. and Blanco, M., 1984. Les diatomées fluvio-lacustres Plio-Pléistocènes de la Formation Charaña (Cordillère Occidentale des andes, Bolivie. Cah. ORSTOM, Sér. Géol. 14, pp. 55-102.

Servant-Vildary, S. and Mello e Sousa, S.H., 1993. Paleohydrology of the Quaternary saline Lake Ballivian (southern Bolivian Altiplano) based on diatom studies. Int. J. Salt Lake Res. 2, pp. 69-85.

Servant-Vildary, S., 1978. Les diatomées des dépôt lacustres quaternaires de l'Altiplano Bolivien. Cah. ORSTOM, Sér. Géol. 10, pp. 25-35.

Servant-Vildary, S., 1978. Les diatomées des sédiment superficiels d'un lac salé, chloruré, sulfaté sodique de l'Altiplano Bolivien, le lac Poopó. Cah. ORSTOM, Sér. Géol. 10, pp. 79-89.

Servant-Vildary, S., 1984. Les diatomées des lac sursalés Boliviens. Sous-Classe Pennatophycidées I - Familie des Nitzschiacées. Cah. ORSTOM, Sér. Géol. 14, pp. 35-53.

Servant-Vildary, S., 1986. Les diatomeés actuelles des Andes de Bolivie (Taxonomie, écologie). Cah. Micropal. N.S. 1, pp. 99-124.

Servant-Vildary, S., 1992. Phytoplankton. In: Dejoux, C., Iltis, A. (Eds.), Lake Titicaca. A Synthesis of Limnological Knowledge. Monogr. Biol. 68. Kluwer Academic, Dordrecht, pp. 163-175.

Simonsen, R., 1987. Atlas and Catalogue of the Diatom Types of Friedrich Hustedt. J. Cramer, Berlin. Vol. 1, Catalogue, 525 pp.; Vol 2., Atlas, Pl. 1-395; Vol. 3, Atlas, Pl. 396-772.

Snoeijs, P., Kasperovičienè, J. (Eds.), 1996. Intercalibration and Distribution of Diatoms Species in the Baltic Sea. Vol. 4. The Baltic Marine Biologists. Opulus Press, Uppsala, pp. 1-125.

Stuiver, M., Reimer, P.J., Bard, E., Beck, J.W., Burr, G.S., Hughen, K.A., Kromer, B., McCormac, F.G., v.d. Plicht, J. and Spurk, M., 1998. INTCAL98 Radiocarbon age calibration 24,000-0 cal BP. Radiocarbon 40, pp. 1041-1083. V

Stute, M., Forster, M., Frischkorn, H., Serejo, A., Clark, J.F., Schlosser, P., Broecker, W.S. and Bonani, G., 1995. Cooling of tropical Brazil $\left(5^{\circ} \mathrm{C}\right)$ during the Last Glacial Maximum. Science 269, pp. 379-383.

Sylvestre, F., 2002. A high-resolution diatom reconstruction between 21,000 and $17,000{ }^{14} \mathrm{C}$ yr BP from the southern Bolivian Altiplano (18-23ㅇ). J. Paleolimnol. 27, pp. 45-57.
Sylvestre, F., Servant, M., Servant-Vildary, S., Causse, C., Fournier, M. and Ybert, J.-P., 1999. Lake-level chronology on the Southern Bolivian Altiplano $\left(18^{\circ}-23^{\circ} \mathrm{S}\right)$ during late-Glacial time and the early Holocene. Quat. Res. 51, pp. 54-66.

Sylvestre, F., Servant-Vildary, S. and Roux, M., 2001. Diatom-based ionic concentration and salinity models from the south Bolivian Altiplano (15-23오. J. Paleolimnol. 25, pp. 279-295.

Sylvestre, F., Servant-Vildary, S. and Servant, M., 1998. Le dernier maximum glaciaire (21000-17000 ${ }^{14} \mathrm{C}$ ans BP) dans les Andes tropicales de Bolivie d'après l'étude des diatomées. C. R. Acad. Sci. Paris Série IIa 327, pp. 611-618.

Sylvestre, F., Servant-Vildary, S., Fournier, M. and Servant, M., 1996. Lake-levels in the southern Bolivian Altiplano $\left(19^{\circ}-21^{\circ} \mathrm{S}\right)$ during the Late Glacial based on diatom studies. Int. J. Salt Lake Res. 4, pp. 281-300.

Thompson, L.G., Davis, M.E., Mosley-Thompson, E., Sowers, T.A., Herdenson, K.A., Zagorodnov, V.S., Lin, P.-N., Mikhalenko, V.N., Campen, R.K., Bolzan, J.F., Cole-Dai, J. and Francou, B., 1998. A 25,000-year tropical climate history from Bolivian Ice-cores. Science 282, pp. 1858-1864.

Valero-Garcés, B.L., Grosjean, M., Schwalb, A., Mebus, G., Messerli, B. and Kelts, K., 1996. Limnogeology of Laguna Miscanti: evidence of mid to late Holocene moisture changes in the Atacama Altiplano (Northern Chile). J. Paleolimnol. 16, pp. 1-21.

Van der Hammen, T. and Asby, M.L., 1994. Amazonia during the last glacial. Palaeogeogr. Palaeoclimatol. Palaeoecol. 109, pp. 247-261.

Vincent, W.F., Wurstbaugh, W., Neale, P.J. and Richerson, P.J., 1986. Polymixis and algal production in a tropical lake: latitudinal effects on the seasonality of photosynthesis. Freshw. Biol. 16, pp. 781-803.

Wirrmann, D., 1992. Geomorphology and sedimentation. Morphology and bathymetry. In: Dejoux, C., Iltis, A. (Eds.), Lake Titicaca. A Synthesis of Limnological Knowledge. Monogr. Biol. 68. Kluwer Academic, Dordrecht, pp. 16-22.

Wirrmann, D., Ybert, J.-P., Mourguiart, P., 1992. A 20,000 years paleohydrological record from Lake Titicaca. In: Dejoux, C., Iltis, A. (Eds.), Lake Titicaca. A Synthesis of Limnological Knowledge. Monogr. Biol. 68. Kluwer Academic, Dordrecht, pp. 40-48. 